\title{
APROXIMACIÓN CRÍTICA A LA HISTORIOGRAFÍA DE SAN ISIDORO DE LEÓN*
}

\author{
Aida GARCÍA MARTÍNEZ \\ Universidad Autónoma de Madrid
}

\begin{abstract}
RESUMEN: A pesar de ser la Iglesia de San Isidoro de León uno de los monumentos mejor documentados de la Edad Media española carece todavía hoy de un estudio monográfico exhaustivo. En este trabajo nos proponemos realizar un estado de la cuestión de las distintas interpretaciones que de él se han venido publicando desde el siglo XIX hasta hoy.
\end{abstract}

PALABRAS CLAVE: San Isidoro de León. Fases constructivas. Monarcas leoneses. Panteón. Infantado.

ABSTRACT: In spite of the fact that San Isidoro de León church is one of the best documented monuments of the Spanish Middle Ages and being an extense bibliography available, there isn't any monographic study which could clarify the doubts which it arouses. In this article we undertake the study on its famous and outstanding pantheon; our goal is to present a brief research of the different interpretations of the material which has been publishes since the XIXth century.

KEYWORDS: Church of San Isidoro de León. Constructive stages. Monarchs of León. Pantheon. Infantado.

Nos proponemos en este trabajo, no el estudio de San Isidoro en sí, que aún y a pesar de todo sigue siendo una cuenta pendiente, sino llevar a cabo un análisis historiográfico o, dicho de otro modo, un estado de la cuestión de las distintas interpretaciones que de él se han venido publicando desde el siglo XIX hasta hoy. Para ello realizaremos un breve recorrido por la historia constructiva del conjunto, unida a los sucesivos monarcas desde Fernando I, haciendo especial hincapié en el controvertido panteón real, para concluir con el análisis del posible papel que jugaron las mujeres de la familia real y, en el fondo, el supuesto protagonismo del

\footnotetext{
* Quiero agradecer a la profesora Margarita Torres la atención deparada en mi trabajo, así como al profesor Pedro García Martín por todas las oportunidades que me está brindando. Mi agradecimiento también a mis compañeras Sara Pérez y Galia Pik por sus aportaciones a este artículo. Gracias, finalmente, a la profesora Concepción Abad Castro por su continuo apoyo y sus valiosísimos consejos.
} 
Infantado, en la configuración de un edificio tan paradigmático, en la historia y evolución de las formas artísticas del prometedor reino cristiano de León.

El siglo XI español está inserto dentro de un contexto sumamente complejo como es el de la Reconquista española. Por ello es desgraciadamente un período bastante desconocido y en consecuencia no bien estudiado de nuestra historia, tanto desde la óptica cristiana como desde la musulmana, ya que ha sido prácticamente ignorado al encontrarse constreñido entre dos "etapas de esplendor": el arte de repoblación por parte de la dinastía astur en el siglo X y la eclosión del románico en el XII, así como el arte califal del siglo X y el almohade a partir del XII; constituyendo así un período intermedio con aparentes connotaciones de transición. Sin embargo, durante su desarrollo se produjeron importantísimos cambios en todos los ámbitos, principalmente en la Iglesia, que provocaron un período de inestabilidad política. En este proceso jugó un papel esencial la ciudad de León, convertida en una urbe regia heredera del poderío y esplendor del antiguo reino astur, donde además tomará cuerpo esa "idea imperial leonesa", de manos de Fernando I fundamentalmente y materializándose con sus sucesores Sancho II "EL Fuerte" de Castilla y Alfonso VI, bajo cuyo gobierno capitula la ciudad de Toledo, antigua capital del reino hispano-visigodo.

El templo de San Isidoro de León ha constituido desde su origen uno de los emplazamientos más emblemáticos y simbólicos dentro del panorama arquitectónico hispánico, al haber estado vinculado a la familia real castellanoleonesa, erigiéndose como iglesia palatina y dando cobijo en su interior al cementerio real. Además, su importancia estriba también en el hecho de que tradicionalmente ha sido considerado como el primer templo románico conocido dentro del reino de Castilla y León ${ }^{1}$.

Paradójicamente, a pesar de ser uno de los monumentos mejor documentados de la Edad Media española ${ }^{2}$, también es uno de los más problemáticos en cuanto a datación y atribución, a pesar de conservarse un número considerable de documentos relacionados con su construcción y contar con una amplísima

\footnotetext{
${ }^{1}$ Así la describía ya en 1910 José Ramón Mélida: "por lo que fue considerada tal fábrica como la más antigua de las debidas en Castilla al etilo románico"; MÉLIDA, J.R., «La Basílica legionense de San Isidoro», Boletín de la Real Academia de la Historia, Tomo LVI, 1910, pp. 148-153.

${ }^{2}$ Sobre este edificio se conservan diferentes inscripciones, entre ellas la lápida de consagración, el pergamino original de dotación, las inscripciones funerarias de los donantes, la crónica sobre la historia de España escrita aproximadamente en torno al 1130 por un monje del propio monasterio de San Isidoro, etc...
} 
bibliografía publicada al respecto, por lo que continúa siendo necesario un estudio sistemático del edificio.

\section{LOS ORÍGENES}

La controversia persigue a nuestro edificio desde sus más remotos orígenes. Las fuentes conservadas relativas a este tema no se ponen de acuerdo en la atribución de los diferentes edificios que constituían el primitivo complejo de lo que hoy conocemos como la Colegiata de San Isidoro de León.

De este modo, las crónicas del siglo XIII señalan la existencia de un monasterio en este lugar bajo la advocación de San Pelayo. Este monasterio, al parecer, sería restaurado por Alfonso V, quien además construiría junto a él la iglesia de San Juan Bautista. Sin embargo Ambrosio de Morales, viajero del siglo XVII que visitó nuestro templo, atribuye a este monarca la restauración del monasterio de San Pelayo y el cambio de advocación de éste por la de San Juan Bautista.

Para intentar dar un poco de luz a estas interpretaciones, debemos remontarnos a la primera fundación de este edificio. La historiografía más antigua ${ }^{3}$ se muestra de acuerdo en atribuir a Sancho I el Gordo (956-966) la fundación de un monasterio femenino en León, el cual fue enriquecido con las reliquias del niño mártir Pelayo, de quién tomó el nombre de Monasterio de San Pelayo ${ }^{4}$. Sin embargo, a los pocos años de su fundación Almanzor amenaza con profanar las iglesias de León, con lo que la abadesa del monasterio, Doña Elvira, hermana de Sancho I, decide huir con toda la comunidad a los montes cantábricos para refugiarse finalmente en el monasterio de San Pelayo de Oviedo, donde depositaron las reliquias del santo y de donde nunca más salieron.

Efectivamente, las amenazas del caudillo Almanzor se cumplieron y la ciudad fue arrasada a finales del siglo X, por lo que el panorama con el que se encontraría Alfonso V (999-1027) cuando tomó posesión del Reino de León, no sería muy alentador. En este sentido, la principal obra que se debe atribuir a este monarca es sin duda la restauración de la ciudad, no sólo a un nivel arqueológico, sino a nivel

\footnotetext{
${ }^{3}$ Nos referimos a autores como Yepes, Risco, etc... y aún en el siglo XX, autores como Gómez Moreno siguen defendiendo esta postura.

${ }^{4}$ Gómez Moreno aún se atreve a ir más lejos al afirmar que anterior a la fundación de Sancho I, existió otra de la época, quizá, de Ordoño I, producto por tanto del arte asturiano del momento, imaginando que se trataría de una iglesia angosta, muy elevada, realizada en piedra y abovedada, del tipo de la de San Miguel de Lillo o San Salvador de Valdediós. Un buen estudio de la iglesia de San Isidoro de León en todas sus etapas constructivas lo tenemos en Gómez Moreno, M., Catálogo Monumental de España. Provincia de León, Madrid, 1925.
} 
de recuperación de la urbe regia que había sido anteriormente, otorgándola fueros y restaurando y construyendo iglesias a la vez que combatía contra los musulmanes.

Por tanto, en lo relativo a la actuación de Alfonso $\mathrm{V}$ en la iglesia que nos ocupa, el único dato que se conserva es una inscripción que dice: "Et fecit Ecclesiam hanc de luto, et latere", con lo que no es posible deducir si se trataría de una iglesia de nueva construcción dedicada a San Juan Bautista y añadida al monasterio ya existente, o si, como apunta Ambrosio de Morales, Alfonso V se limitó a restaurar el monasterio existente, cambiándolo al mismo tiempo de advocación.

Hay que señalar en este punto que las fuentes siempre se refieren a San Juan Bautista como una iglesia atendida por monjes varones ${ }^{5}$, mientras que el monasterio, en su condición de femenino, estaría atendido por monjas ${ }^{6}$. Algunos autores han apuntado la posibilidad de que se tratara de un monasterio dúplice ${ }^{7}$ debido a la existencia de ambas comunidades. Al parecer, tanto la comunidad de monjas como la de monjes estaban bajo la dependencia de la infanta Teresa, hermana de Alfonso V, identificada por algunas fuentes como viuda de Almanzor ${ }^{8}$.

Podemos resumir de todo lo expuesto hasta ahora que existió un monasterio femenino bajo la advocación de San Pelayo, y una iglesia dedicada a San Juan

5 Probablemente los mismos que atenderán a Fernando I, cuando decidió morir haciendo penitencia en la propia iglesia de San Isidoro, como veremos detalladamente más adelante.

${ }^{6}$ Según Julio Pérez Llamazares, el Tudense hace referencia a que Alfonso V fundó o hizo por primera vez esta iglesia, pues este significado es el que se debe atribuir a la palabra -fecit-, mientras que al hablar del monasterio de San Pelayo, dice que lo restauró - restauravit-. A la iglesia le da ya el nombre de San Juan Bautista, puesto que esta crónica se escribió dos siglos después de lo acontecido. Este autor realiza un estudio completo sobre la Colegiata de San Isidoro de León en PÉREZ Llamazares, J., Historia de la Real Colegiata de San Isidoro de León (Edición facsimil), León, 1927.

${ }^{7}$ Ver por ejemplo Gómez Moreno, M., Catálogo Monumental..., Op. Cit. (n. 4) o Pérez Llamazares, J., Historia de la ... Op. Cit. (n. 6).

${ }^{8}$ Algunas fuentes cuentan que Almanzor, para humillar al rey de León Vermudo II, había tenido el capricho de reclamarle una de las hijas para su harén cordobés. Finalmente la hizo su esposa ligítima, ordenando que cuando él muriese la devolvieran a León, cargada de honores y leyendas. Al llegar a León, Doña Teresa ingresó en el monasterio de San Pelayo construido por su hermano, movida probablemente por su gran devoción al niño mártir $\mathrm{y}$, para acompañar los restos se trasladó al monasterio de San Pelayo de Oviedo, donde recibió sepultura. Ver «La Real Colegiata de San Isidoro» en Enciclopedia del Románico en Castilla y León, Aguilar de Campoo, 2002, pp. 534-566, esp. 534-539. Esta misma hipótesis es defendida por PÉrez Llamazares, J., Historia de la ... Op.Cit. (n. 6). Esta historia parece tener un sentido más fantástico y literario que real, ya que si Doña Teresa regresó a León tras la muerte de Almanzor, ¿quién arrasó la ciudad de León provocando la huida de la comunidad femenina del monasterio de San Pelayo?. 
Bautista. Esta iglesia estaba construida con materiales pobres - de luto et latere-, pero de ella no se ha conservado nada. La hipotética reconstrucción de este edificio se ha realizado a través del estudio de la iglesia atribuida a Fernando I, cuyos cimientos se encontraron bajo el suelo de la actual iglesia tras unas excavaciones llevadas a cabo por el arquitecto Torbado a principios del siglo XX. Se sabía de la existencia de este templo por el epitafio del rey Fernando I, donde se especifica: "Fecit ecclesiam hanc lapideam que olim fuit lutea", de lo que se ha deducido que existía una iglesia realizada de materiales pobres que él levantó en piedra. Las excavaciones sacaron a la luz una iglesia de tres naves y cabecera tripartita de testeros rectos y escalonados (Fig. 1); por tanto, se trata de una iglesia de clara tradición asturiana que, al estar sustituyendo a la anterior, hace suponer que la de Alfonso $\mathrm{V}$ también se tratara de una iglesia de tradición asturiana, cuyo precedente más próximo se ha visto en la iglesia de San Salvador de Valdediós. Además, sabemos por la descripción que las fuentes hacen sobre la iglesia de San Juan Bautista que bajo el altar dedicado a San Martín, enterraban los restos de eclesiásticos y en un cuerpo occidental dedicado a cementerio real, se dieron sepultura los padres de Alfonso V, Bermudo II y doña Elvira, y el propio Alfonso? No hay duda que la construcción de este panteón a los pies de la iglesia se realizó a imitación del de la iglesia de Santa María de Oviedo construido por su antecesor Alfonso II (792-842), quien construyó una urbe regia a la que llamó Oviedo, siguiendo evidentemente el modelo de la célebre capital hispanovisigoda, Toledo. La idea de construir un cementerio real está ligada no sólo a una idea de estabilidad y continuidad del reino, sino que también está implícita la intención de demostrar ante un pueblo la procedencia de un linaje; en este caso, ambos están pretendiendo la misma cosa: demostrar y justificar la procedencia de su linaje de los reyes visigodos de Toledo. Al parecer, esta idea de construir un panteón real propio, proviene de tiempos de Ramiro II (931-950) quien, ante la decisión de su única hija de tomar los hábitos, decidió levantar un monasterio junto a, o formando parte del palacio real y lo dedicó al Salvador, conocido con el nombre de monasterio de San Salvador de Palat del Rey, al parecer con una clara intención de relacionar las dos ciudades reales, Oviedo y León. En este cementerio fue donde se enterraron Ramiro II, Ordoño III (m. 956) y Sancho I el Gordo (m. 966). No obstante, hay que tener en cuenta que otros reyes como Ramiro III (m. 985) o Vermudo II (m. 999), tomaron sepultura en otros monasterios.

9 La inscripción dice exactamente:"H. Jacet Rex Adefonsus, qui populavit Legiones pos destrutionem Almanzor dedit bonos foros, fecit Ecclesiam hanc de luto, latere. Habuit praelia cum Sarracenis, interfectos est sagitta apud Viseum in Portugal. Fuit filius Veremundi Ordonii. Obit Era MLXV.III. Non. Dec", RisCo, M., Iglesia de León, y Monasterios antiguos y modernos de la misma ciudad, Madrid, 1978, pp. 148-149. 


\section{LA IGLESIA DE FERNANDO I}

A la muerte de Alfonso V (999-1027) la situación política del Reino leonés no era demasiado estable, tanto en el orden interno como en la relación con otros reinos, principalmente el navarro. Aquí gobernaba Sancho el Mayor (1004-1035), quien logró someter a su hegemonía todos los territorios cristianos a excepción de los condados catalanes, donde destacó la figura de Berenguer Ramón I. Por su parte los reinos musulmanes, tras la muerte de Almanzor inician un proceso de desintegración, formándose los reinos de Taifas, hecho que será aprovechado por los reyes cristianos para recuperar territorios.

Con Sancho el Mayor comenzaron los contactos con el mundo ultrapirenaico, aunque hoy en día no es posible conocer las dimensiones exactas que pudieron alcanzar éstos ${ }^{10}$; no obstante, la realidad es que a partir del reinado de Sancho III se afianzaron las relaciones entre ambos lados de la cordillera pirenaica, lo que supuso a su vez el contacto con el mundo de las mentalidades de la Europa que estaba gestando la génesis del románico ${ }^{11}$. Durante su reinado también invade León, donde reinaba el joven Bermudo III (1028-1037), hijo de Alfonso V, y último descendiente de la estirpe cántabro-astur, a quien usurpa el honorífico título de "emperador" con que los escribas describían a los reyes de León. A su muerte decide dividir su reino entre sus hijos, correspondiendo Castilla a Fernando, quien se casará con Sancha, hermana del rey de León, Bermudo III. Inmediatamente surgen divergencias entre los dos cuñados, que desembocarán en la Batalla de Tamarón en 1037, con la derrota y muerte del soberano leonés. Esta situación produjo una nueva unión entre Castilla y León, ya que Fernando toma posesión del reino de León en nombre de su esposa. En este sentido se ha venido insistiendo en el contraste de la herencia ideológica entre ambos cónyuges; mientras que a Fernando, heredero de la tradición navarra se le atribuyen ideas de renovación y

${ }^{10}$ Un estudio exhaustivo y de sumo interés sobre las relaciones que se establecieron entre los reinos castellano-leoneses y los franceses, concretamente con la abadía de Cluny, lo tenemos en BISHKo, Ch., «Fernando I y los Orígenes de la alianza castellano-leonesa con Cluny», Cuadernos de Historia de España, vol. XLVII-XLVIII, 1968, pp. 31-135. Gracias a las investigaciones de este autor sabemos que Sancho el Mayor mantuvo relaciones directas con el abad Odilo de Cluny como socius y familiares, lo que le aseguraba la participación en los méritos espirituales de los monjes y en las súplicas litúrgicas diarias por todos los socii de la abadía, vivos y muertos, y la perpetua conmemoración de su óbito, como sucedería también a la muerte de Fernando I. Ver p. 38 del trabajo de Bishko.

${ }^{11}$ BANGo Torviso, I. G., «La piedad de los reyes Fernando I y Sancha. Un tesoro sagrado que testimonia el proceso de la renovación de la cultura hispana del siglo XI», Maravillas de la España Medieval: Tesoro sagrado y monarquia, León, 2001, pp. 223-227, esp. 225. 
modernidad, a su esposa Sancha, por el contrario, heredera de la tradición leonesaasturiana, se la considera más ligada a la vieja idea imperial y al visigotismo. Sin embargo, esto debe tomarse con sumo cuidado, ya que las investigaciones de Bishko demuestran el activo papel de la reina a la hora de estrechar las relaciones con Cluny, lo cual está perfectamente demostrado en las intercesiones que el abad Hugo estableció para ambos tras la muerte de la reina Sancha en $1067^{12}$.

Como vemos, los herederos de Sancho el Mayor de Navarra continuaron con la política de abrir las fronteras hacia los reinos europeos más próximos. A esto ayudó además las circunstancias que acompañaron al reinado de Fernando I, cuyas tropas consiguieron someter a las principales taifas, consiguiendo así fronteras seguras y obteniendo cuantiosos beneficios tributarios. Todo unido propició un importante esplendor económico que favorecerá el desarrollo de las artes.

Podemos concluir que, durante el reinado de Fernando I y Sancha (1037-1065) se produce en territorio castellano-leonés una "total renovación de la cultura de sus estados" ${ }^{\prime \prime}$, lo que se tradujo, desde el punto de vista artístico, en el abandono de las formas que constituían el antiguo patrimonio hispano, para dejar paso a las nuevas formas del románico, las cuales irán entrando mediante la importación de objetos suntuarios, adquiridos en un principio exclusivamente por los reyes, quienes además propiciaron la entrada de artistas extranjeros que trabajaban de acuerdo a la "modernidad". Desde el punto de vista arquitectónico, las formas del románico irán entrando paulatinamente en territorio castellano-leonés, siendo lo normal que en un principio se aprovecharan los edificios construidos, los cuales se sometían a una ampliación o remodelación con las nuevas formas. Esta y otras circunstancias fueron las que contribuyeron a crear lo que el profesor Bango ha denominado, "formas híbridas", y que se mantuvieron durante largo tiempo. Este va a ser el caso de la iglesia de San Isidoro de León construida por Fernando I, como veremos detalladamente a continuación.

En cuanto a la iglesia propiamente dicha, la historiografía más antigua atribuía la actual iglesia a Fernando $\mathrm{I}^{14}$. Sin embargo, las excavaciones del arquitecto

12 BishKo, Ch., «Fernando I y...», art. cit .(n. 10), p. 75. Estos privilegios eran, por supuesto, a cambio de cuantiosas sumas de dinero que se donaban a la abadía de Cluny, como muy bien explica Bishko en su trabajo.

13 BANGo Torviso, I. G., El arte románico en Castilla y León, Madrid, 1997, p. 108.

${ }^{14}$ Así lo expresa por ejemplo Don Manuel Risco: "El edificio de la Iglesia actual del Convento de San Isidro fue erigido por el Rey don Fernando I hacia los años de 1060 para colocar en él el cuerpo del glorioso Doctor San Isidoro...."; Risco, M., Iglesia de León... Op. cit. (n. 9), p. 144. Igualmente, Don Ambrosio de Morales en la descripción que de esta iglesia hace en su viaje de 1572, dice: 
Torbado y, posteriormente las del profesor Williams, dieron un giro radical a la interpretación del edificio, sacando a la luz los restos de una iglesia encontrada bajo el suelo de la actual, cuya planta responde a una iglesia basilical de tres naves, con una cabecera tripartita de testeros rectos y escalonados, perfectamente atribuible a iglesias de tradición asturiana, y cuyo paralelo más cercano se ha querido ver en la iglesia de San Salvador de Valdediós en Oviedo ${ }^{15}$. Sin embargo, no deja de llamarnos la atención el hecho de que Fernando I construyera una iglesia ligada a una tradición anterior, cuando a él, y como ya hemos visto, se le atribuyen ideas de renovación y modernidad. Esto se ha explicado básicamente desde dos perspectivas: la primera en relación a un posible "respeto" por parte de Fernando I hacia sus antepasados; aunque en este sentido sería más lógico pensar que ese respeto proviniera más de su esposa Sancha que de él, puesto que es ella la descendiente del linaje asturiano; y la segunda hipótesis tiene que ver con la costumbre de aprovechar edificios ya construidos, en este caso, reaprovecharían los cimientos de la iglesia de Alfonso V, tal y como era costumbre de la época. No debemos olvidar, sin embargo, que hoy día el aspecto de esta iglesia es una incógnita, por lo que no se debe descartar la posibilidad de un alzado románico, quedando esta iglesia perfectamente integrada en la mentalidad artística de este monarca. Nos encontraríamos pues ante una iglesia de planta asturiana y alzado románico, lo que el profesor Bango a denominado en algunos de sus trabajos como "tipologías híbridas"16, las cuales fueron muy abundantes y se mantuvieron durante mucho tiempo ${ }^{17}$.

"Después el Rey D. Fernando el primero, cuando trujo aquí el Cuerpo del Glorioso Doctor S. Isidoro, edificó mas ampla y ricamente, y dotó de nuevo, y llamó el Monasterio del nombre del Santo Doctor, quedandose todavía de Monjas, pues que hasta el Emperador D. Alonso, hijo de D. Urraca no vinieron a el los Canonigos Reglares que agora estan, como por Escrituras de privilegios parece". Por tanto vemos como no hace ninguna alusión a posibles construcciones posteriores a Fernando I, atribuyendo pues a éste el aspecto actual de la iglesia. Morales, A., Viaje Santo. Viaje a los Reinos de Leon, y Galicia, y Principado de Asturias, Ed. Facsímil, Oviedo, 1977, pp. 41-42.

${ }^{15}$ Los primeros en advertir estas similitudes fueron GómEZ Moreno, M., Iglesias mozárabes, Madrid, 1919, 76-81; Id., Catálogo Monumental... Op. cit., (n. 4), p. 186; y SchlunK, H., y MANZANAReS, J., «La Iglesia de San Pedro de Teverga y los comienzos del arte románico en el Reino de Asturias y León», Archivo Español de Arte, XXIV, 1951, pp. 277-305.

16 Así lo explica por ejemplo en BANGO TORviso, I. G., «Arquitectura y escultura monumental», Historia de España de Menéndez Pidal, Tomo XI, Madrid, 2001, pp. 344-414 (p. 370).

${ }^{17}$ El profesor Bango cita varios edificios construidos con esta misma tipología, tales como las iglesias de San Pedro de Teverga (Asturias), San Bartolomé de Rebordanes (Pontevedra), San Pedro de Ansemil (Pontevedra) o Santa María de Corticela (Santiago de Compostela). BAngo Torviso, I. G., Alta Edad Media. De la tradición hispanogoda al Románico, Madrid, 1989, p. 96. 
Volviendo al epitafio de Fernando $\mathrm{I}^{18}$, hay en él un hecho de suma importancia y que no debemos pasar por alto y al que las fuentes aluden constantemente. Nos referimos a la clara matización de la utilización de la piedra en la fábrica de este edificio frente al ladrillo de la construcción de Alfonso V. Se está dejando clara la diferencia entre el viejo sistema constructivo de ladrillo y tapial, que por otro lado perdurará hasta el final de la modernidad, y la "relativa novedad" de la utilización de la sillería románica. De este modo Fernando I y Sancha están haciendo alarde de su poder económico al sufragar una construcción enteramente realizada en piedra.

Hoy en día, prácticamente la totalidad de los investigadores se muestran de acuerdo con lo hasta ahora expuesto en este trabajo respecto a la iglesia construida por el matrimonio real de Fernando I y Sancha. El problema viene a la hora de atribuir el Panteón con su tribuna, las galerías norte y occidental y la torre (Fig. 2).

\section{EL PANTEÓN: LA PROBLEMÁTICA HISTORIOGRÁFICA}

Probablemente sea este Panteón la construcción más discutida y problemática del patrimonio medieval español. A su estudio se han dedicado los mejores especialistas y sobre él se han escrito infinidad de páginas llenas de hipótesis, de las cuales ninguna ha podido ser demostrada dada la complejidad de la construcción del edificio, motivada sobre todo por las muchas remodelaciones que ha sufrido. Como consecuencia, en este apartado nos limitaremos principalmente a exponer las hipótesis más relevantes y que más han influido en el estudio de este edificio.

En este sentido, el principal problema radica en dos aspectos: la atribución de la construcción y su función. En cuanto a la atribución, los estudiosos dudan entre Fernando I y su hija la Infanta doña Urraca; mientras que en lo concerniente a la función de este espacio, los investigadores se dividen en dos posturas: los que lo consideran un nártex o pórtico de entrada, y los que defienden la realización de un panteón siguiendo la tradición hispánica.

Pero antes de empezar a desarrollar las diferentes hipótesis, debemos centrarnos en los motivos que llevaron a Fernando I y Sancha a construir un cementerio real en esta iglesia, aunque algunos de éstos ya han sido expuestos más arriba. Lo primero que debemos destacar a este respcto es la personalidad de Fernando I. Son muchos los documentos que lo describen como un personaje profundamente religioso y gran favorecedor de iglesias y monasterios, a los cuales dotaba de gran

18 "Fecit ecclesiam hanc lapideam que olim fuit lutea". 
largueza ${ }^{19}$. Esto entroncaría con la imponente alianza que mantuvo con la abadía de Cluny $^{20}$, considerada como una de las casas de mayor prestigio y poder dentro de la Cristiandad Occidenta ${ }^{21}$. En cuanto al lugar de enterramiento, por su condición de heredero de la estirpe navarra al ser hijo de Sancho el Mayor, le correspondía enterrarse en el panteón real del monasterio de Oña, aunque su primera intención fue la elección del monasterio de Arlanza por el que sentía una devoción especial ${ }^{22}$ por su nueva condición de Rey de Castilla, y para cuyo fin hizo trasladar los restos de los mártires abulenses Vicente, Sabina y Cristeta $^{23}$. Sin embargo, su esposa Sancha le convenció de la conveniencia de enterrarse en este monasterio de San Juan Bautista de León, aludiendo a la amenidad del lugar, la salubridad de los aires, la fecundidad de su huerta, la abundancia de sus aguas, la extensión de sus florestas y choperas, la delicia de sus montes, etc... ${ }^{24}$ Marta Poza Yagüe ha querido ver en esta elección de León como lugar de enterramiento el motivo principal de la reedificación en sillería de la antigua iglesia de San Juan Bautista y San Pelayo ${ }^{25}$, construida por Alfonso $\mathrm{V}$ en ladrillo ${ }^{26}$.

19 Sobre este particular también se pronuncia Valdés Fernández, atribuyendo la nueva construcción de la iglesia a la política real de ayuda a la Iglesia castellano-leonesa por parte de Fernando I, insistiendo en la idea de que este monarca protegió todos los monasterios de su reino aunque, al parecer, fue bastante más generoso con los castellanos que con los leoneses. Ver VALDÉs FERnÁndeZ, M., «El Panteón Real de la Colegiata de San Isidoro de León», Maravillas de la España Medieval... Op. Cit, (n. 11), pp. 73-84 (p. 77).

${ }^{20}$ Ya hemos explicado cómo se establecieron estas relaciones. Ver nota 10.

${ }^{21}$ PozA YAGÜE, M., «Entre la tradición y la reforma. A vueltas de nuevo con las portadas de San Isidoro de León», Anuario del Departamento de Historia y Teoría del Arte (U.A.M), Vol. XV, 2003, pp. 9-28 (p. 11).

${ }^{22}$ ViÑAYO, A., «La llegada de San Isidoro a León. Datos para la historia del traslado del Cuerpo del Doctor de las Españas desde Sevilla a León (1063)», Archivos leoneses, no 33 (XVII), 1963, pp. 65-112 (p. 75).

${ }^{23}$ Poza YaGÜE, M., «Entre la tradición...», Art. cit. (n. 21) p. 11.

${ }^{24}$ VIÑAYO, A., «La llegada...», Op. cit. (n. 22) p. 76.

${ }^{25}$ PoZA YaGÜE, M., «Entre la tradición...», Art. cit. (n. 21) p. 11.

${ }^{26}$ Este hecho, como la mayoría de los relacionados con esta iglesia, no se puede demostrar, puesto que entra de lleno en la problemática de la datación del edificio, no pudiéndose establecer con claridad la fecha de inicio y finalización de las obras. Sí que sabemos por una escritura fechada el 1 de julio de 1037, que Fernando I había elegido el monasterio burgalés de Arlanza como lugar de enterramiento (Ver Serrano, L., Cartulario de San Pedro de Arlanza, Madrid, 1925, pp. 63-66). De aquí podemos deducir que si la reedificación de su iglesia comenzó antes de 1037, la hipótesis de Marta Poza habría de descartare; por el contrario, si el comienzo de las obras es posterior, como probablemente debió ocurrir, tendríamos aquí los motivos que llevaron a este monarca a construir un panteón real en esta iglesia. 
Una vez tomada la decisión de establecer aquí su panteón real, donde estaban enterrados Alfonso V y Bermudo III $^{27}$, Fernando I, al parecer incitado por su esposa, decidió trasladar aquí los restos de su padre Sancho el Mayor de Navarra y, lo que es aún más importante, ennoblecer a la iglesia del cementerio real $^{28}$. La iglesia de San Juan Bautista ya poseía insignes reliquias, entre las que destacaba, sin ninguna duda, la mandíbula del Bautista que daba nombre al templo. Sin embargo, tras esta importante decisión, ambos monarcas determinaron que éstas no eran suficientes y que debían dotar al templo de nuevo material sacro, para lo que decidieron trasladar los restos del ilustre San Isidoro desde Sevilla a León.

Las particularidades de este traslado se narran en las llamadas Actas de Traslación $^{29} \mathrm{y}$, de una forma más abreviada, en la Historia Silense ${ }^{30}$, escrita a comienzos del siglo XII en León, además de en Los Milagros de San Isidoro de Lucas de Tuy $^{31}$. La tradición oficial cuenta que Fernando I hizo un pacto con el rey de Sevilla al-Muta'did, conocido en las fuentes como Abenhabet, por el cual el monarca cristiano se comprometía a retirar su ejército y suspender la guerra contra el caudillo musulmán a cambio de un ostentoso tributo y el cuerpo de Santa Justa ${ }^{32}$. Para ello mandó una comitiva a Sevilla encabezada por los obispos Alvito y Ordoño, los cuales tenían el encargo de encontrar y trasladar a León los restos de esta mártir. Sin embargo, la "providencia" quiso que no encontraran el sepulcro de la santa, y fue entonces cuando San Isidoro, en nocturna aparición, reveló a Alvito el lugar de su sepulcro y la divina voluntad de que fuese su cuerpo y no el de Santa Justa el concedido a la ciudad de León ${ }^{33}$.

${ }^{27}$ Padre y hermano de la reina Sancha.

${ }^{28}$ Es de sobra sabido que las iglesias se valoraban por la cantidad y calidad de las reliquias que poseían. Además, hemos de tener en cuenta lo que pudo suponer la pérdida de las reliquias de San Pelayo para nuestra iglesia, por lo que, probablemente lo que realmente pretendían Fernando I y Sancha era paliar y remplazar los restos de dicho mártir.

29 Documento dividido en nueve lecciones para ser recitadas en los maitines de la solemnidad litúrgica del 22 de diciembre, fecha en la que se celebra la fiesta de la traslación. Ver ViÑAYO, A., «Cuestiones histórico-críticas en torno a la traslación del cuerpo de San Isidoro», Isidoriana, León, 1961, pp. 285-297.

${ }^{30}$ Historia Silense, Madrid, 1959.

${ }^{31}$ LuCAS DE TúY, Milagros de San Isidoro, León, 1992.

32 Santa Justa fue una virgen hispanorromana que fue martirizada con su hermana Rufina el 19 de Julio de 287. Esta elección no debe parecer sorprendente, puesto que el nombre de Santa Justa fue uno de los primeros que entraron en el Santoral mozárabe. Ver VIÑAYO, A., «Cuestiones históricocríticas...», Art. cit. (n. 29), pp. 287-288.

${ }^{33}$ ViñAYO, A., «La llegada...», Op. cit, (n. 22), p. 80. 
En opinión don Antonio Viñayo, este infortunado incidente no tiene nada que ver con la intervención sobrenatural del Doctor de las Españas, sino que fue un propósito público o secreto de los embajadores antes de llegar a Sevilla y que, probablemente no se estipuló en el pacto porque parecería excesivo pago ${ }^{34}$. Con esto, está dando a entender la primitiva intencionalidad por parte de la embajada leonesa de traer las reliquias de San Isidoro, previa a su partida hacia Sevilla. Su hipótesis va aún más lejos, aventurándose a afirmar que Fernando I y Sancha eran cultural y espiritualmente isidorianos ya antes de efectuarse el traslado ${ }^{35}$.

Independientemente de las razones verdaderas de su traslado, lo cierto es que los restos del Padre de las Españas llegaron a León para autorizar y honrar la iglesia del cementerio real a finales de diciembre del año 1063, consagrándose el templo el día 21 del mismo mes en honor del santo, cambiando desde este momento su advocación por la de San Isidoro. Este hecho provocó un extraordinario aumento de la popularidad y devoción a este santo, hecho que pudo influir de cierta manera en la decisión de Fernando I de escoger este escenario ${ }^{36}$ para interpretar un complicado rito funerario cuando en 1065, tan sólo dos años después del traslado, decidió recrear los últimos días del santo hispalense ${ }^{37}$ muriendo en penitencia pública ${ }^{38}$. Este marcado carácter penitencial parece estar rodeando cada aspecto de la vida de este monarca y muy probablemente estaría determinado por un profundo sentimiento de culpabilidad nacido desde el asesinato

${ }^{34} I d$.

35 Para explicar esta circunstancia se basa en el Concilio de Coyanza celebrado en 1050, convocado y presidido por el propio matrimonio real y que, según su opinión, fue plenamente isidoriano. Además, alude al hecho de que las obras literarias escritas por San Isidoro eran copiadas en los escritorios monacales de todo el reino astur-leonés desde el siglo VIII y, además, en este tiempo eran muy frecuentes los monasterios que se gobernaban por la regla isidoriana. Ibid., pp. 8081.

${ }^{36}$ Los restos de San Isidoro se colocaron en una arqueta ricamente decorada y se dispusieron delante del altar mayor del templo.

${ }^{37}$ Estos acontecimientos fueron analizados por BISHKO, Ch., «The Liturgical Context of Fernando I's Last Days According to the So-Called 'Historia Silense'». Miscelánea en Memoria de Dom Mario Férotin, 1914-1964. Hispania Sacra, Vols. XVII-XVIII, 1964-1965, pp. 47-59.

${ }^{38}$ En el año 1065 Fernando I convocó a la corte, se vistió con las ropas reales y ordenó que le llevasen a la iglesia donde, ante la urna de San Isidoro oró a Dios. Concluida la oración, se despojó de sus ricos ropajes, para sustituirlos por un cilicio, y de la corona para cubrirse la cabeza con cenizas; posteriormente, se arrepintió de sus pecados, los obispos le absolvieron y le administraron la extremaunción; durante dos días hizo penitencia. El tercer día, festividad de San Juan Bautista, cuando era la hora sexta, entregó su alma sin mancha a Dios. Ver VALDÉs FernÁndeZ, M., «El Panteón Real...», Art. cit. (n. 19), p. 75. 
de su cuñado Bermudo III en Tamarón y, más aún desde los de sus hermanos García y Ramiro en Atapuerca y Graus respectivamente. Serafín Moralejo ha justificado esta actitud de los últimos días de Fernando I como parte de su programa imperial o, lo que parece más lógico, como expiación de los pecados cometidos a lo largo de su jalonada vida ${ }^{39}$. Este mismo carácter penitencial se ha visto en uno de los objetos más representativos donado por el matrimonio real con motivo de la recepción del cuerpo de San Isidoro ${ }^{40}$; se trata del famoso crucifijo de marfil, cuya iconografía está basada en la Muerte y la Resurrección ${ }^{41}$.

Volviendo al estudio histórico-artístico del panteón, el principal problema que se nos plantea es su datación y atribución. Al parecer, tres son las hipótesis que se barajan entre los investigadores: la primera viene a defender que Fernando I y Sancha construyeron la nueva iglesia y el panteón entre 1054 y 1067, ya que una inscripción concerniente al papel que jugó Sancha (m. 1067) en la construcción del edificio así lo expresa, "Sancia regina Deo dicata peregit". Además, el hecho de que esta inscripción se encontrara originalmente en uno de los pilares del porche del panteón ${ }^{42}$, avala la teoría de que este espacio estaba al menos comenzado a la muerte de la reina en $1067^{43}$. La segunda hipótesis mantiene que fue Urraca, la hija de Fernando I y Sancha, la que construyó el panteón tal y como hoy lo conocemos,

39 Moralejo, S., «Artistas, patronos y publico en el arte del Camino de Santiago», Compostellanum, XXX, nº 3-4, 1985, pp. 395-423 (p. 411).

${ }^{40}$ Con motivo de la solemne consagración del templo el 22 de diciembre de 1063, Fernando I y Sancha realizan una amplísima dotación -como manda la tradición- de objetos para el culto, ajuar doméstico y bienes muebles e inmuebles. Sobre este aspecto resulta muy interesante el trabajo realizado por el profesor don Isidro Bango. BANGO, I. G., «La piedad...», Art. cit. (n. 11), p. 223.

${ }^{41}$ Para el estudio de esta pieza y, especialmente de su iconografía, ver FernÁndEz SOMOZA, G., «Cruz de Fernando I y Sancha», Maravillas de la España Medieval: Tesoro Sagrado y Monarquía, León, 2001, pp. 230-231, nº cat. 88.

42 VAldeZ Del ÁlAmo, E., «Ortodoxia y Heterodoxia en el estudio de la Escultura Románica Española: Estado de la cuestión», Anuario del Departamento de Historia y Teoría del Arte (U.A.M), Vols. IX-X, 1997-1998, pp. 9-33 (p. 14).

${ }^{43}$ Entre los partidarios de esta hipótesis destacan GómEz Moreno, M., El arte románico español. Esquema de un libro, Madrid, 1934; GaIllarD, G., La sculpture romane espagnole 1. De Saint Isidore de Leon à Saint Jacques de Compostelle, París, 1946, pp. 19-21; RoBB, D., «The Capitals of the Panteón de los Reyes, San Isidoro de León», The Art Bulletin, no 27 (3), 1945, pp. 165-174; VIÑAYO, A., «El arte románico leonés. Nuevas cuestiones», León medieval. Doce estudios, León, 1978, pp. 221-232; ID., San Isidoro de León. Panteón de Reyes. Albores románicos: arquitectura, escultura y pintura, León, 1995; BANGO TORVISO, I. G., «El espacio para enterramientos privilegiados en la arquitectura medieval española», Anuario del Departamento de Historia y Teoría del Arte (U.A.M), Vol. IV, 1992, pp. 93-132; CALDWELL, S., «Urraca of Zamora and San Isidoro in León: Fulfillment of a Legacy», Woman's Art Journal, no 7 (1), 1986, pp. 19-25. 
entre 1072 y 1101, fecha de su muerte. Esta es la opinión más generalizada, y viene justificada por la interpretación del epitafio de esta infanta en el cual se puede leer: Haec ampliavit ecclesiam Istam, de donde se ha deducido que la palabra "ampliavit" se refiere a la ampliación de la iglesia de sus padres y a la construcción del cementerio real ${ }^{44}$. Por último, existe una tercera hipótesis que defiende una postura intermedia, donde el panteón habría sido comenzado por Fernando I y Sancha y terminado por su hija Urraca al mismo tiempo que amplió la iglesia ${ }^{45}$.

La historiografía más antigua, defendida por autores como Gómez Moreno o Gaillard, atribuye el panteón real, tal y como hoy lo vemos, a la época de Fernando I, aceptando el año 1063 como fecha en la que los trabajos ya estarían concluidos. Estos autores basaban sus propuestas en la relación encontrada entre los documentos conservados y el estudio del edificio. Hasta ese momento, nadie se había cuestionado esta relación de documento a monumento y, mucho menos, se ponía en duda las fechas conocidas y tradicionalmente aceptadas sobre la construcción de la iglesia de Fernando I y su panteón, hasta que John Williams, tras dos campañas de excavaciones realizadas en la iglesia de San Isidoro (1969 y 1971), propuso la idea de que Fernando I y Sancha no eran los artífices del panteón, sino que fue su hija Urraca la que lo construyó, fechándolo en torna 1080. Williams basa sus declaraciones, además de en las posibles pruebas encontradas en sus campañas arqueológicas, en las conclusiones de autores como Gaillard o Durliat. El primero, a pesar de atribuir la iniciación de las obras del panteón a Fernando I, y más concretamente a la campaña de 1054, reconoce la presencia de capiteles en el panteón que son muy similares a algunos encontrados en el interior de la basílica fechados en el siglo XII ${ }^{46}$. Este hecho fue el que llevó a Durliat a

${ }^{44}$ El mayor defensor de esta teoría es Williams, J., «San Isidoro in León: Evidence for a New History», The Art Bulletin, $\mathrm{n}^{\circ} 55$ (2), 1973, pp. 171-184; Id., «León: The Iconografy of the Capital», Cultures of power: Lordship, status and process in Twelfth-century Europe, 1995, pp. 231-258; junto a él autres como: MORALEJO, S., «Le origini del programma iconografico dei portali nel romanico spanoglo», Actas. Wiligelmo e Lanfranco nell'Europa romanica, Módena, 1989, pp. 35-51; FERNÁNDEZ GonZÁlez, E., San Isidoro de León, Madrid, 1991.

45

Partidario de esta teoría es el profesor Durliat, M., L'Art Roman en Espagne, París, 1962; mientras que Elisabeth VALDÉs Del ÁlAmo, en su artículo «Ortodoxia y Heterodoxia...», art. cit (n. 42) hace partícipe de esta hipótesis al profesor BANGO, I. G., Alta Edad Media ..., Op. cit. (n. 17), p. 134. No parece que don Isidro esté diciendo esto exactamente, sino que simplemente alude a que "comenzando el último tercio de siglo, o poco antes, se procedería a una transformación del panteón regio [...] con la aparición de motivos escultóricos en capiteles y cornisas". Es decir, atribuye a Urraca una actuación en el panteón meramente decorativa.

${ }^{46}$ GAILlard, G., Les débuts de la sculpture romane spagnole. Leon, Jaca, compostelle, París, 1938. 
cuestionarse la fecha de 1063 para el panteón, siendo el primero que se atreviera a ponerlo en duda públicamente ${ }^{47}$. En cuanto a las conclusiones dadas por el profesor Williams fruto de sus excavaciones está la reconocida disparidad estilística entre la iglesia de Fernando I y el panteón ${ }^{48}$, ya que mientras la iglesia se adhiere en su planta al estilo tradicional asturiano, por lo que ha sido comparada con la iglesia de San Salvador de Valdediós, el pórtico, sin embargo, está levantado en el nuevo estilo románico, deduciendo así que están realizados en diferentes épocas ${ }^{49}$. En este sentido, compara el panteón, para él "pórtico" o nártex abovedado, con la tipología de iglesia-porticada tipo Westwerk, desde que Gómez Moreno ${ }^{50}$ estableciera su semejanza con el pórtico de la Iglesia abacial de Saint-Benoît-Sur-Loire ${ }^{51}$. De este modo afirma que el panteón o pórtico fue construido después y adosado a la iglesia, fechándolo entonces a finales del siglo XI. Para demostrar estas afirmaciones se basa en unas pruebas encontradas en el muro norte y occidental de la iglesia, ambos restos reconocidos de la primitiva iglesia de Fernando y Sancha, donde durante la restauración del historiador don Menéndez Pidal se pudo observar el paramento completo del muro, el cual estaba realizado (según el profesor Williams) con un "raro" sistema escalonado para reducir el grosor del muro a medida que se va ascendiendo. Este mismo sistema se puede ver en los contrafuertes fernandinos que flanqueaban la primitiva puerta occidental de la iglesia. Según este investigador, los constructores del edificio no se hubieran tomado la molestia de realizar estos contrafuertes con esta peculiar decoración, si estas paredes se hubieran concebido para ser tapadas con la galería norte que hoy se conserva y con el panteón. Esto le lleva a afirmar que tanto el panteón como la galería norte fueron concebidos y ejecutados después de la campaña que realizó la iglesia. Con esta teoría consigue además dar explicación a la "disparidad estilística del panteón" en relación con la iglesia, puesto que los considera realizados en diferentes épocas ${ }^{52}$.

${ }^{47}$ Durliat, L'Art... Op.Cit. (n. 45), p. 18.

48 Tanto Gómez Moreno como Gaillard reconocen este hecho aunque, como muy bien afirma el profesor Williams, lo ignoran completamente a la hora de datar el edificio. GómEZ MORENO, M., Catálogo Monumental..., Op. cit. (n. 4), p. 182; Gaillard, G., Les débuts..., Op. cit. (n. 46), p. 3.

49 En palabras del propio Williams: “One encounters a complete rejection of the Spanish tradition”; Williams, J., «San Isidoro in León...», Art. cit, (n. 44), p. 173.

${ }^{50}$ Gómez Moreno, M., Catálogo Monumental..., Op. cit. (n. 4), p.182.

${ }^{51}$ Para Gómez Moreno, este pórtico es posterior al panteón, ya que lo supone comenzado por el abad Gozlín en 1069, Gómez Moreno, M., Id.; mientras que, si hacemos caso de la hipótesis de Williams, este pórtico francés sería anterior a la construcción de nuestro panteón.

52 Williams, J., «San Isidoro in León...», art. Cit, (n. 44), pp. 176-177. 
Llegados a este punto, nos topamos con otra de las polémicas del edificio relacionada con la datación de la galería norte, la nave occidental del panteón, la tribuna y la parte baja de la torre. Los primeros en pronunciarse al respecto fueron Gómez Moreno y Gaillard ${ }^{53}$, quienes atribuyeron la totalidad de estos espacios a la campaña de Fernando I, con la diferencia de que Gaillard considera que tanto la galería norte, como la nave occidental del panteón que une a éste con la muralla, se concibieron y ejecutaron después de que el panteón fuese erigido, aunque deja muy claro que fue inmediatamente después. Para ello se basa en una serie de incongruencias en los arcos que comunican ambas naves y en las pilastras de los contrafuertes divisorios de la galería, los cuales originariamente se alzaban verticalmente para formar una fachada norte y que, con la adición de la galería tuvieron que ser retocados para soportar los arcos de las bóvedas ${ }^{54}$, convirtiéndose en pilastras y embellecidos con columnas y capiteles historiados en un estilo ya plenamente románico. Sin embargo, el profesor Williams, basándose en esta última afirmación de Gaillard, considera una conclusión irrefutable que la galería y el panteón fueron construidos por el mismo taller, puesto que él encuentra en algunos de los capiteles de la galería, claras similitudes a los dos grandes capiteles centrales del panteón ${ }^{55}$. En conclusión, dicho autor llega a afirmar que tanto el panteón, la galería, la tribuna, como la parte baja de la torre se deben fechar a finales del siglo XI y por tanto atribuir su ejecución a la Infanta Urraca ${ }^{56}$. Respecto a la tribuna sobre el panteón añade que, ni Gómez Moreno ${ }^{57}$ ni Gaillard ${ }^{58}$ consideran que una bóveda de la envergadura de la de la tribuna, de unos ocho metros, no puede ser compatible con una fecha tan temprana como la de 1063, por lo que consideran que tendría una cubierta de madera, la cual fue sustituida por la actual bóveda de piedra en el siglo XII con la construcción de la nueva basílica. Esta desatinada propuesta a

${ }^{53}$ Gomez Moreno., M., Catálogo Monumental..., Op. cit. (n. 4); Id., El arte románico..., Op. cit, (n. 43); Gaillard, G., Les débuts..., Op. cit. (n. 46).

${ }^{54}$ Gaillard, G., Les débuts..., Op. cit, (n. 46), p. 6.

${ }^{55}$ Concretamente Williams se refiere a un capitel preciso de la galería decorado con bolas, el cual es análogo en estructura y decoración a uno de los grandes capiteles del centro del panteón; al igual que hay otros, donde este último también se incluye, que poseen una peculiar moldura en el collarino que hace que se los considere de la misma época y taller. Williams, J., «San Isidoro in León...», art.cit. (n. 44), p. 176.

\footnotetext{
${ }^{56}$ Id., p. 179.

${ }^{57}$ Gómez Moreno, M., Catálogo Monumental..., Op. cit. (n. 4), p. 185.

${ }^{58}$ GaIllard, G., Les débuts..., Op. cit. (n. 46), pp. 3-4.
} 
los ojos del profesor Williams se rechazaría si se atribuyera la construcción de la tribuna a finales del siglo $\mathrm{XI}^{59}$.

Prácticamente la totalidad de las teorías vertidas por Williams han sido cuestionadas por otros investigadores, principalmente por el profesor Isidro Bango. Según él, en lo concerniente a la iglesia de Fernando I, el hecho de tener un trazado planimétrico de tipo asturiano no implica necesariamente un desarrollo en altura con los mismos principios constructivos. De este modo se remite a la iglesia de San Salvador de Valdediós donde, según el profesor Bango, se produjo una "renovación de su pasado", cuyo alzado constituye una obra, desde el punto de vista constructivo, meramente románica ${ }^{60}$. En su opinión, son numerosísimos los edificios prerrománicos cuyos muros son cortados hasta una cierta altura para después edificar sobre ellos con un léxico ya románico ${ }^{61}$, y esto mismo es lo que probablemente ocurrió con la iglesia de Alfonso V, reconstruida por Fernando I y en el panteón con la ampliación de la infanta Urraca. Otro importante ejemplo ${ }^{62}$ al que don Isidro hace referencia y que al parecer se construyó a imitación de la iglesia fernandina, es el templo de San Pedro de Teverga en Asturias. Aquí hubo una primera construcción, cuyos muros fueron cortados para que sirviesen de fundamento, levantándose sobre ellos la nueva iglesia románica. Al igual que ocurre en San Isidoro de León, la estructura prerrománica condiciona la forma de la construcción románica, surgiendo así lo que el profesor Bango ha llamado una solución "híbrida" 33 .

En este mismo sentido, el propio Isidro Bango ha llamado la atención sobre diferentes objetos suntuarios creados en el taller eborario que existió en León durante el reinado de Fernando I y Sancha; concretamente hace referencia al relicario de San Juan Bautista y San Pelayo, conocido como Arca de San Isidoro de

${ }^{59}$ Williams, J., «San Isidoro in León...», Art. cit. (n. 44), p. 180.

${ }^{60}$ Bango Torviso, I. G., Alta Edad Media ..., Op. cit. (n. 17), p. 86.

${ }^{61}$ BAngo Torviso, I. G., «El camino jacobeo y los espacios sagrados durante la Alta Edad Media en España», Viajeros, peregrinos, mercaderes en el Occidente Medieval. XVIII Semana de Estudios Medievales, Estella 1991, Navarra, 1992, pp.121-155; Id., «El espacio para enterramientos...», Art. cit. (n. 43), pp. 104-105; Id., "Arquitectura y escultura», Historia del Arte de Castilla y León. Arte Románico, Tomo II, Valladolid, 1994, pp. 9-212, p. 21; Id., «Arquitectura y escultura...», Art. cit. (n. 16), p. 370.

62 Decimos importante porque como ya sabemos, son escasísimos los ejemplos conservados de construcciones románicas del siglo XI en territorio castellano-leonés.

63 Bango Torviso, I. G., «Arquitecura y escultura», Art. cit. (n. 61), p. 27; Id., El arte Románico..., Op. cit. (n. 13), p. 110; Id., «Arquitectura y escultura...», Art. cit. (n. 16), p. 370 у 396. Ver también página 6 de este trabajo. 
León, donación de la pareja real al monasterio de San Juan y San Pelayo, en cuya decoración hay arquillos de herradura con decoración vegetal y de medio punto con billetes y $\operatorname{tacos}^{64}$, estos últimos con un esquema arquitectónico que responde al típico vano de edificio del románico pleno, por lo que no sería inadmisible pensar que, el maestro eborario de esta caja podría estar transmitiendo la composición de las arquitecturas de su entorno y por qué no la de San Isidoro de León, que en estos momentos se encontraría en plena construcción ${ }^{65}$. Con esta teoría quedaría demostrado el alzado románico de la iglesia sobre una planta de tradición asturiana.

En cuanto al panteón, el planteamiento es muy parecido al anterior ${ }^{66}$, es decir, en palabras del propio Isidro Bango "de una vieja fórmula hispana 'disfrazada' con

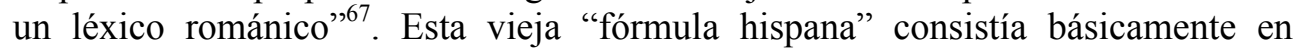
colocar un contra ábside a los pies de las iglesias el cual permitía crear un espacio autónomo, pero íntimamente relacionado con el interior del templo, adecuándose así al precepto del concilio bracarense, celebrado en el siglo VI, que prohibía enterrar en el interior de los templos ${ }^{68}$; de este modo este espacio quedaba aislado de la nave central mediante un muro en el que sólo se abría una puerta y al que las fuentes denominan "habitatio sepulchri" ${ }^{\prime 69}$. El mejor ejemplo de panteón regio de la Alta Edad Media es la iglesia de Santa María de Oviedo, construida por Alfonso $\mathrm{II}^{70}$, con la única diferencia que el panteón ovetense ocupa únicamente el espacio de la nave principal, mientras que el isidoriano, para solucionar el problema de

${ }^{64}$ Bango Torviso, I. G., El arte Románico..., Op. cit. (n. 13), p. 118.

${ }^{65}$ Id., «Arquitectura y escultura», Art. cit. (n. 61), p. 21.

${ }^{66}$ Parece ser que el profesor Bango en su interpretación del Panteón comparte la teoría expuesta por Díaz Jiménez, quien ya en 1917 expresa su rechazo a considerar el panteón como nártex de la iglesia, puesto que, en sus propias palabras "el muro de cerramiento por el ocaso se halla adosado al lienzo de la antigua muralla; que el acceso por la parte del claustro se encuentra embarazado por los anchos zócalos que de éste le separan, y que desde luego debió ser construido para panteón lo patentizan los cuatro arcos entrantes que hay en sus muros no ligados con arcatura y destinados, tal vez, para colocar bajo ellos las urnas sepulcrales”. Ver DíAZ-JIMÉNEZ, J. E., «San Isidoro de León», Boletín de la Sociedad Española de Excursiones, Madrid, 1917, pp. 81-98 (p. 94).

${ }^{67}$ Id., «Arquitectura y escultura...», Art. cit, (n. 16), p. 370.

${ }^{68} I d .$, «El espacio para enterramientos...», Art. cit. (n. 43), p.101.

${ }^{69}$ Id., Arte prerrománico hispano. El arte en la España cristiana de los siglos VI al XI, en Summa Artis. Historia General del Arte, Vol. VIII-II, Madrid, 2001, p. 89.

${ }^{70}$ El precedente más claro de esta estructura occidental es la basílica de Nicodemes Miranda, fechada aproximadamente en el año 600. Un perfecto estudio de estas estructuras y su simbología, lo tenemos en el ya citado trabajo del profesor BANGo, Arte prerrománico hispánico..., Op. cit. (n. 69). Para comprender el significado de esta construcción en el templo isidoriano, nos remitimos a la página 4 de este trabajo. 
espacio que se había generado en Santa María por la saturación de tumbas, se amplió a las tres naves ${ }^{71}$. Según el profesor Bango la finalidad de este "pórtico" es "ad tumulandum", es decir, un lugar privilegiado de enterramiento ${ }^{72}$.

En lo concerniente a la identificación de este espacio con un Weskwert carolingio, este mismo autor deja muy clara la diferencia fundamental entre estas dos estructuras: mientras que en los "macizos occidentales" el piso bajo se corresponde con un hall de entrada, que comunica la calle con el interior del templo, en San Isidoro este espacio es un espacio cerrado al exterior, al que sólo se puede acceder desde el interior de la iglesia por una única puerta ${ }^{73}$. Además, según este mismo autor, la tribuna del segundo piso, en el caso de León, su construcción no pertenece al proyecto original, sino que fue un añadido posterior, al parecer ya del siglo XII ${ }^{74}$, basándose de nuevo en la construcción de la iglesia de San Pedro de Teverga, construida como ya hemos dicho a imitación del templo leonés, la cual también careció de tribuna en su origen hasta que se le añadió el coro en época moderna $^{75}$. Por tanto, las semejanzas encontradas, por ejemplo con el pórtico de Saint-Benoît-Sur-Loire, en cuanto a estructura y espacio se refiere, son puramente accidentales.

Otro de los investigadores que ha cuestionado las teorías de Williams, ha sido Antonio Viñayo, canónigo archivero de San Isidoro, quien en varios de sus trabajos se hace preguntas relacionadas con las diferentes teorías de San Isidoro de León ${ }^{76}$.

71 Tenemos constancia de este hecho por el ilustre Ambrosio de Morales, quien en su Viaje describe el panteón con estas palabras: "El enterramiento de los muchos Reye que aquí estan sepultados, es una Capilla de Santa Catalina, que está al cabo de la Iglesia, entendiendose manifiestamente como ellos escogieron este lugar tan apartado del Altar mayor por humildad [...]. La capilla esta siempre cerrada, y no la abren sino para mostrarla a personas que es razon, y porque estan los sepulcros llanos y muy juntos unos con otros [...] porque como estan las sepulturas muy juntas con el Altar, hay poco espacio [...]. La Capilla es escura..... Ver Morales, A., Viaje Santo..., Op. cit. (n. 14), p. 42.

72 BANGO TORVISO, I. G., «Atrio y pórtico en el Románico español: concepto y finalidad cívicolitúrgica», Boletín de Seminario de Estudios de Arte y Arqueología, Tomos XL-XLI, Valladolid, 1975, pp. 175-188, (pp. 179-180).

${ }^{73}$ Id., Arte prerrománico... Op. Cit. (n. 69), p. 378; ID., «El camino jacobeo...», Art. cit. (n. 61), p. 146.

${ }^{74}$ Id., El Románico en España, Madrid, 1992, p. 233.

75 Posiblemente, el hecho de que esta iglesia carezca de cementerio y la estructura occidental sirva de pórtico y no de panteón, sea porque no se trata de una iglesia palatina, como ocurre en San Isidoro de León.

${ }^{76}$ ViñAYO, A., «El arte románico...», Art. cit. (n. 43); Id., San Isidoro de León..., Op. cit. (n. 43). 
Entre ellas destacan dos: si, como afirman varios estudiosos, la iglesia de Fernando y Sancha es una de las mejores documentadas de nuestra historia medieval, ¿por qué Williams cuestiona la relación de documento a monumento?; además, si estos documentos sólo mencionan la iglesia, ¿cómo sabe el profesor Williams que fue la infanta Urraca, y no Sancha o su marido, la que construyó el panteón?. Según Viñayo, los únicos datos en los que se apoya Williams para demostrar sus teorías, son el avance de las técnicas, especialmente escultóricas, que aparecen en el panteón y la comprobación de que el panteón es una construcción adosada y por ello posterior a la iglesia ${ }^{77}$. A este respecto el padre Viñayo se pregunta si tal adosamiento es cierto, y de ser así, qué precede a qué, ya que las hiladas de sillares de la iglesia y el panteón se corresponden en los paramentos de uno y otro edificio, así como las técnicas de construcción ${ }^{78}$. Como ya sabemos, en opinión de este destacado investigador, el panteón fue construido por Fernando I, sólo que él lo considera un pórtico de entrada y no una estructura cerrada al exterior, junto con los pórticos que los circundan y la tribuna. Sin embargo, afirma que estos pórticos no fueron planeados con el panteón, ni formaron parte del proyecto originario de este, sino que muy poco después de construido lo que él considera el nártex de la iglesia, se le adosaron y fueron decorados por el mismo escultor ${ }^{79}$.

\section{LA “AMPLIACIÓN” DE LA INFANTA URRACA}

Al parecer, el mismo día de la consagración de la iglesia de Fernando I y Sancha, el ya anciano rey dio a conocer su decisión de repartir su reino entre sus tres hijos varones ${ }^{80}$, correspondiendo al mayor, Sancho II, el territorio de Castilla, al segundo, Alfonso VI, el reino de León, y al más joven, García, Galicia; mientras que a sus hijas, las dejaba en posesión de los llamados "infantados" ${ }^{81}$. Con la muerte de la reina Sancha en 1067 el territorio castellano-leonés entra en un período de guerra, iniciado por el rey Sancho, quien consideraba que su condición de primogénito le daba pleno derecho a poseer la totalidad de la herencia de su padre, pretendiendo reunificar los tres reinos con Castilla como centro. Después de

${ }^{77}$ VIÑAYO, A., «El arte románico...», Art. cit. (n. 43), p. 226.

${ }^{78}$ Ibid., p. 228.

${ }^{79}$ Id., San Isidoro de León..., Op. cit. (n. 43), p. 27.

${ }^{80}$ CAdlwell, S., «Urraca of Zamora...», Art. cit. (n. 43), pp. 19-45 (p. 19).

${ }^{81}$ La Institución del Infantado se refiere a un conjunto de monasterios propiedad de princesas reales o infantas, sobre los que ejercían un gran poder jurisdiccional y administrativo. Esta cuestión es de sumo interés para el estudio de la iglesia de San Isidoro, por lo que a él dedicaremos un apartado de nuestro trabajo. 
una etapa de conflictos entre los tres hermanos, Sancho consiguió capturar a García y Alfonso, enviándoles al exilio, con la consiguiente alegría de los castellanos y la desolación de los leoneses, quienes a pesar de la situación y mientras ésta duró, continuaron encabezando sus documentos con Reinante rege Adefonso in Legione $^{82}$.

Analizada la situación, Urraca y Alfonso se aliaron para organizar una resistencia contra su hermano en la fortificada ciudad de Zamora, que anteriormente le había regalado Alfonso y de la que ella se sentía reina ${ }^{83}$. Esto provocó una situación de gran tensión cuya única solución parecía estar en la muerte de alguno de los dos hermanos y, concretamente será la de Sancho II. En esos momentos, los castellanos atribuyeron a Urraca la maquinación del asesinato de su rey, incluso en el epitafio de Sancho se puede leer: "La muerte de este rey se produjo por consejo de su hermana, Urraca de Zamora, por la mano de Vellido Adolfo, un gran traidor" ${ }^{\prime \prime 4}$; lo que ha llevado también a que muchas fuentes la describan como una mujer muy inteligente, cruel, calculadora, mentirosa e incluso, se la ha catalogado de incestuosa, por no estar clara la relación que mantenía con su hermano Alfonso. Con la muerte de Sancho II en 1072, Alfonso VI recuperó su trono, con la única diferencia que a partir de ahora no gobernaría sólo, sino junto a su hermana Urraca, quien desde este momento se hará llamar reina. Un año más tarde, en 1073, Alfonso decide para evitar problemas, encarcelar a su hermano García en el Castillo de Luna, donde falleció en 1090, consiguiendo así reunir todo el territorio bajo un mismo reino.

Son varias las hipótesis que intentan explicar el por qué de este valioso apoyo por parte de Urraca a su hermano Alfonso sobre sus demás hermanos. Susan Cadlwell sostiene que la reina Sancha debió trasmitir a su hija, la infanta Urraca, la admiración por la antigua dinastía leonesa y lo que ella significaba en cuanto a poder y reputación. En este sentido, esta autora opina que todas las hazañas documentadas de Urraca, incluso el apoyo a su hermano Alfonso, lo que la pudo haber llevado incluso a involucrarse en el asesinato de su hermano Sancho, se deben interpretar en pos de su interés por León, puesto que Alfonso fue el heredero de este reino y a él pertenecía su infantado ${ }^{85}$.

${ }^{82}$ CADlwell, S., «Urraca of Zamora...», Art. cit. (n. 43), p. 21.

${ }^{83}$ De aquí es de donde parece provenir el calificativo de Urraca de Zamora.

${ }^{84}$ La inscripción completa, realizada en latín, se puede encontrar en MENÉndez PIDAL, R., La España del Cid, Vol. I, Madrid, 1969, pp. 186-187.

${ }^{85}$ Cadlwell, S. H., «Urraca of Zamora...», Art. cit. (n. 43), p. 21. 
En cuanto al reinado de Alfonso VI, quien como ya hemos visto, consiguió en 1072 unificar de nuevo Castilla y León, tal y como lo había estado durante el gobierno de su padre; durante su mandato consiguió engrandecer su territorio, luchó y derrotó tanto a enemigos musulmanes como cristianos y estableció fuertes alianzas con Francia a través sobre todo de matrimonios ${ }^{86}$. Al parecer, al igual que hiciera su padre, siguió con la tradicional donación de oro a la abadía de Cluny, llegándola a duplicar en $1077^{87}$. Uno de los hechos históricos más significativos de este monarca por sus connotaciones, más simbólicas que estratégicas, es sin ninguna duda, la reconquista de la ciudad de Toledo en 1085, a la que siguieron otras tantas hazañas de igual fortuna contra los mismos musulmanes. Estos, al ver cómo sus territorios se iban reduciendo en manos del ya conocido con el apelativo de "El Bravo", se vieron obligados a pedir ayuda a sus vecinos los almorávides, quienes consiguieron parar los avances del rey cristiano en la Batalla de Sagrajas. Antes de su muerte y en vista de la ausencia de un hijo varón que le sucediera, viaja a Toledo en el año 1109 para proclamar como sucesora a su hija Urraca, hecho sin precedentes en la historia de la Península y que provocó una situación difícil de manejar. Pero antes de hablar de la Reina Urraca, debemos ocuparnos de su tía, la Infanta Urraca, hermana del Emperador Alfonso VI.

Al parecer, la infanta Urraca continuó los pasos de su madre en cuanto al patrocinio de San Isidoro se refiere. Prácticamente la totalidad de los investigadores están de acuerdo en afirmar que fue a partir de 1072, con el restablecimiento en el poder de su hermano, cuando Urraca comenzó sus actuaciones en la iglesia de sus padres. Como ya hemos dicho en otras ocasiones, el

${ }^{86}$ Alfonso VI se casó varias veces. Su primera mujer fue Inés de Aquitania (1074-1077), con la que no tuvo descendencia, por lo que decidió repudiarla para casarse con Constanza de Borgoña (1079-1093), sobrina del Abad Hugo de Cluny. Esta alianza le sirvió a su vez para fortalecer sus vínculos con la abadía de Cluny y de ella nació su hija Urraca, la que se convertiría en Reina de Castilla y León. Se casó después con Berta de Lombardía (1094-1100), de la que tampoco tuvo descendencia. De su cuarta esposa no se sabe mucho, Doña Isabel de Francia (1100-1106), sí que con ella tuvo dos hijas, Sancha y Elvira; después de ésta, se le atribuye una relación con la princesa musulmana Zaida, sobre la que no hay unanimidad en las fuentes ya que algunas la consideran hija del rey Almamum de Toledo, o incluso nuera de éste, y otras fuentes hablan de que es hija del rey sevillano Abenabeth, o Muhammad b. 'Abbad al'Mutamid. Paradójicamente fue ésta última la que le dio su único hijo varón, Sancho Alfónsez, quien desgraciadamente morirá muy joven en la Batalla de Uclés. Parece ser que Zaida se convirtió al cristianismo adoptando el nombre de Isabel, con la que Alfonso VI se casó en 1106 para legitimar a su hijo. Su última mujer, con la que se casó a los 70 años de edad en 1108, se llamaba Beatriz, de la que sólo pudo disfrutar un año, puesto que murió en 1109 $\mathrm{y}$, como es de esperar, no tuvo descendencia.

${ }^{87}$ Martin, Th., Queen as king: Patronage at the Romanesque Church of San Isidoro de León, University of Pittsburgh, 2000, p. 81. 
principal problema radica en la interpretación de la palabra "ampliavit" que aparece en su epitafio:

"Domna Urraca Regina de Zamora, filia Regis magni Fernandi: Haec ampliavit ecclesiam Islam, multis muneribus ditavit. Et quia Beatum Isidorum super omnia diligebat, ejus servitio subjugavit. Obiit era MCXXXVIII, ${ }^{, 88}$

Antes de las excavaciones llevadas a cabo por el profesor Williams, la opinión más generalizada era la de atribuir la cabecera de la actual iglesia, junto con el transepto y los primeros tramos de las naves que siguen a éste, a la iglesia construida por Fernando I (Fig. 3); mientras que a su hija, la Infanta Urraca y de acuerdo con la interpretación de su epitafio, se la atribuía la terminación de la actual iglesia, desde la puerta principal, situada en el muro sur de la basílica, hasta los pies de la Iglesia ${ }^{89}$. Tras esta hipótesis, nos interesa la de Gómez Moreno, quien interpretando la palabra "ampliavit", considera que en época de la infanta Urraca se comenzó la construcción de una nueva iglesia que dio comienzo por la cabecera y en cuyo proyecto original ya se previó la construcción de un transepto ${ }^{90}$. Seguidamente se pronunció sobre este respecto el profesor Gaillard, proponiendo la construcción de una iglesia intermedia entre la de Fernando I y la que actualmente vemos, que también se comenzaría, como es lo normal, por la cabecera. De esta manera atribuye a la infanta Urraca la construcción de una iglesia basilical de tres naves y cabecera tripartita de ábsides semicirculares de la misma profundidad, pero sin transepto (Fig. 4), basando su explicación en un supuesto descubrimiento en los cimientos de la capilla absidial norte, y en un pilar de la presente basílica ${ }^{91}$.

Llegamos en este punto al momento en el que el profesor Williams realiza sus excavaciones, es decir, a la década de los años setenta y, como ya hemos visto anteriormente, sus primeras conclusiones, las cuales le llevaron a afirmar que la ampliación de la infanta Urraca se debía identificar exclusivamente con la construcción del panteón y la galería norte, además de la tribuna y la parte baja de la torre ${ }^{92}$, datándolo consecuentemente hacia finales del siglo XI. Sin embargo, tras numerosas discusiones con colegas e investigadores defendiendo esta postura, por fin en un artículo de 1993 reconoce que esta infanta pudo comenzar los trabajos de

${ }^{88}$ Risco, M., Iglesia de León..., Op. cit. (n. 9), p. 150.

${ }^{89}$ Así se expresa en el trabajo de DíAZ-JiMÉnEZ, J. E., «San Isidoro...», Art. cit. (n. 66), p. 98.

${ }^{90}$ Gómez Moreno, M., El arte románico..., Op. cit. (n. 43), pp. 102-106.

${ }^{91}$ Para una mejor comprensión de sus explicaciones, ver GaILlaRD, G., Les débuts..., Op. cit. (n. 46), pp. 11-13.

92 Williams, J., «San Isidoro...», Art. cit. (n. 43), p. 179. 
ampliación de la iglesia de su padre antes de su muerte en 1101, atribuyendo el transepto a la época de la Reina Urraca, hija de Alfonso VI y sobrina de esta infanta, y la conclusión de las obras a la época de Alfonso VII, hijo de la reina Urraca $^{93}$. No contento con esto, parece ser que las hipótesis del profesor Bango ${ }^{94}$ le hicieron recapacitar hasta el punto de llegar a admitir en un reciente artículo que es difícil imaginar que un cementerio dinástico no formara parte del complejo de Fernando I y que, sólo después de la muerte de Fernando, el panteón asumió su actual forma ${ }^{95}$; por lo que las obras de ampliación debieron comenzar, según él, una vez terminados los trabajos en el panteón y, al igual que Gómez Moreno y Gaillard, también opina que estos trabajos debieron empezar por la cabecera.

En cuanto al profesor Bango, el más destacado defensor del patrocinio del panteón como tal por parte de los reyes Fernando I y Sancha, opina que durante el último tercio del siglo XI, o quizás un poco antes, fue cuando Urraca comenzó la ampliación de la basílica de sus padres, la cual, según su opinión, consistió básicamente en una transformación del panteón regio, añadiendo motivos escultóricos en capiteles y cornisas y, muy probablemente, antes de 1101, fecha de su muerte, habría iniciado la gran ampliación del templo ${ }^{96}$. Esta ampliación consistiría en añadir las galerías circundantes del panteón, tanto la que recorre el muro norte de la iglesia, como la que une el panteón con la muralla por occidente, planteando la duda de si los cinco tramos de la galería norte formarían parte de un claustro, del que no se sabe si se llegó a completar con alguna otra panda. Añade también el profesor Bango, que tanto los capiteles de esta galería como su construcción, se debieron realizar a continuación de las obras del panteón, dadas las similitudes entre ambos. Seguidamente, se comenzarían las obras de una nueva iglesia, ya bajo formas románicas, probablemente con una cubrición de madera ${ }^{97} \mathrm{y}$ que muy pronto sería ampliada por la cabecera ya en la primera mitad del siglo XII, añadiendo además un pronunciado transepto. Esta solución es la misma que se

93 Williams, J., «León and the beginnings of the Spanish Romanesque», The Art of the Medieval Spain: ad 500-1200, The Metropolitan Museum of Art, New York, 1993, pp. 167-173 (p. 170).

94 Ya vimos como el profesor Bango atribuye la construcción del panteón a la época de Fernando I y Sancha.

${ }^{95}$ Williams, J., «León: The Iconography...», Art. cit. (n. 44), pp. 236 y 249.

96 Bango Torviso, I. G., Alta Edad Media ..., Op. cit. (n. 17), p. 133.

${ }^{97}$ Id., «Arquitectura y escultura», Art. cit. (n. 61), p. 66. 
adoptó en una de las ampliaciones de la iglesia de $\operatorname{Silos}^{98}$, con la única diferencia que en esta última se dispusieron absidiolas para aumentar el número de altares, tal y como exigía la nueva liturgia que se estaba implantando en el reino castellanoleonés ${ }^{99}$. Sin embargo, no parece haber sido este el motivo de la adición del transepto a la basílica leonense; más bien debieron ser motivos de espacio lo que llevó a su construcción, tal y como había ocurrido también en la primera ampliación de la iglesia de Santo Domingo de Silos ${ }^{100}$. Según este investigador, se debe diferenciar entre el crucero como ampliación y el crucero como proyecto unitario. De este modo, durante el románico pleno no se conocen cruceros sobresaliendo sobre la anchura de las naves colaterales en un proyecto unitario inicial ${ }^{101}$, sino que este transepto se añadía a edificios basilicales ya construidos, como es el caso de San Isidoro y Santo Domingo de Silos, para así conseguir una ampliación del templo ${ }^{102}$.

Del mismo parecer es la investigadora Susan Caldwell, quien atribuye a la infanta Urraca una importante ampliación que consistió en agrandar la iglesia a la presente anchura y, manteniendo los muros norte y oeste de la iglesia de sus padres, alargó las naves y construyó una cabecera de tres ábsides semicirculares, cuyos cimientos fueron descubiertos bajo el actual transepto. Casi inmediatamente a la finalización de las obras, la iglesia resultó demasiado pequeña debido al gran incremento de peregrinos que pasaban por León en su camino a Santiago de

98 Un completo estudio de esta iglesia lo encontramos en: BANGO TORviso, I. G., «La iglesia de Silos: Del prerrománico al románico pleno», El románico en Silos. IX Centenario de la Consagración de la iglesia y claustro (1088-1988), Abadía de Silos, 1990, pp. 317-376.

99 Para adecuarse a la curia romana, la cual promulgaba la unanimidad entre todas las iglesias mediante la adopción de la regla de San Benito, Alfonso VI ordenó el cambio de liturgia en todas las iglesias de su reino, obligándolas a abandonar el rito mozárabe para adoptar la nueva liturgia romana. Este cambio, como es de esperar, se produjo de una manera paulatina, y conllevaba la transformación de los edificios existentes, puesto que los monjes no podían celebrar más de una misa por altar.

100 BANGo Torviso, I. G., «El camino jacobeo...», Art. cit. (n. 61), p. 144. El profesor Bango explica que tanto en San Isidoro como en Santo Domingo de Silos, la ampliación del crucero se debió a un importante aumento de la comunidad monástica, aunque en San Isidoro, al no existir las absidiolas, hace pensar que lo realmente importante era el espacio destinado a los fieles, el cual, con la adición del transepto, se vería aumentado considerablemente.

${ }^{101}$ Así se construyeron entre otras la iglesia de San Martín de Frómista, la Catedral de Jaca, San Isidoro de Dueñas, San Zoilo de Carrión de los Condes o, como ya hemos visto, la ampliación de Fortunio en Silos.

${ }^{102} I d .$, «Arquitectura y escultura...», Art. cit. (n. 16), p. 380. 
Compostela ${ }^{103}$, por lo que se procedió a desmantelar la cabecera para alargar las naves y construir un transepto terminado en ábsides ${ }^{104}$. Este cambio de proyecto lo atribuye a la infanta Urraca y su terminación se produjo bien entrado el siglo $\mathrm{XII}^{105}$.

En cuanto a la opinión del padre Viñayo, él considera que la llamada "Iglesia nueva", es decir, la que hoy conocemos, se construyó en dos épocas diferentes, en tres etapas sucesivas y por tres arquitectos independientes. De este modo, a la infanta Urraca atribuye las dos primeras etapas que se realizarían en el último tercio del siglo XI; correspondiendo la última etapa a la época de Alfonso VII, en la que se concluirían las partes altas de los muros y las bóvedas, como veremos un poco más adelante ${ }^{106}$.

Sin embargo, la profesora Therese Martin, destacada doctoranda del profesor Williams, atribuye el comienzo de la iglesia románica a la Infanta Urraca antes de su muerte en 1101. Sin embargo, la iglesia con transepto que se llegó a construir se debe atribuir a su sobrina, la reina Urraca ${ }^{107}$, hija de Alfonso VI.

El siguiente documento alusivo a la construcción de San Isidoro, lo encontramos en una inscripción de las Infantas Urraca y Elvira, hijas de Alfonso VI (la primera con $\mathrm{D}^{\mathrm{a}}$ Constanza, y la segunda con $\mathrm{D}^{\mathrm{a}}$ Isabel de Francia), donde se puede leer: "ad laborem", de lo que se deduce que realizaron una donación para las obras del templo que estaban en curso en estos momentos. ¿Qué debemos entender con esto? No parece haber ninguna duda de que se estaba llevando a cabo el segundo proyecto de la infanta Urraca, es decir, el transepto y la nueva cabecera.

${ }^{103}$ En lo relativo a las peregrinaciones y sus influencias en el arte, sobre todo en lo que concierne al Camino de Santiago, sabemos por el profesor Isidro Bango, que estas no influyeron en absoluto en la difusión del estilo románico, como muy bien se puede comprobar tanto en época prerrománica como gótica. En palabras del propio autor: "La peregrinación no contribuye a modificar los planteamientos estilísticos de los lugares por donde discurre". BANGO TORVISO, I. G., «Arquitectura y escultura...», Art. cit. (n. 16), p. 370.

104 Aquí, la profesora Caldwell atribuye a los ábsides la función de absidiolas, cuando forman parte de la cabecera tripartita. Esta es la principal diferencia en cuanto al transepto se refiere, con la iglesia de Silos; mientras que allí, además de las absidiolas del transepto, se construye una cabecera con tres ábsides, en San Isidoro, el transepto carece de estas absidiolas, terminando la iglesia en una cabecera tripartita.

105 CALdwell, S. H., «Urraca of Zamora...», Art. cit. (n. 43), p. 21.

${ }^{106}$ Viñayo, A., La Colegiata de San Isidoro, Madrid, 1979, p. 43.

${ }^{107}$ MARTIN, Th., «Un nuevo contexto para el tímpano de la portada del Cordero en San Isidoro de León», El tímpano Románico, imágenes, estructuras y audiencias, Santiago de Compostela, 2003, pp. 182-205 (p. 194). 
Este repentino cambio en el proyecto, introduciendo un acusado transepto y una nueva cabecera provocó una serie de problemas de adaptación al unir una parte con otra. Estas irregularidades son perfectamente visibles en planta, concretamente en el tercer tramo al oeste del transepto, donde se observa en el muro una clara ruptura en la sillería y un cambio en el eje de la pared de la nueva iglesia con la antigua ${ }^{108}$; también es perfectamente visible cómo los ábsides no coinciden con los muros norte y sur de la iglesia.

\section{LA IGLESIA EN ÉPOCA DE LA REINA URRACA Y DE SU HIJO ALFONSO VII}

Durante los últimos años del siglo XI y los primeros del XII los reinos hispánicos continúan en guerra con los musulmanes. A la muerte de don García en 1090, después de haber permanecido encarcelado por su hermano el rey Alfonso VI, fue cuando la Reina Urraca (1109-1126) se casó con el Conde Raimundo de Borgoña, convirtiéndose ambos en Condes de Galicia; y de este matrimonio nacerán la Infanta doña Sancha y don Alfonso VII (1126-1157).

Las circunstancias que llevaron a doña Urraca al trono fueron más que fortuitas, ya que en 1108, el único hijo varón de su padre Alfonso VI, muere en la batalla de Uclés contra los almorávides, quedando como única y legítima heredera su primogénita Urraca, suceso totalmente nuevo en el reino de Castilla y León. Este hecho provocó que su reinado haya sido descrito de maneras muy distintas y contradictorias por diferentes historiadores. El mismo año de su ascenso al trono, se casa en segundas nupcias con don Alfonso El Batallador, pretendiendo con ello la unión de su vasto territorio con el de Aragón, provocando de este modo fuertes desavenencias entre los dos reinos, en lo que se ha conocido como uno de los matrimonios más turbulentos de la historia de Castilla y León.

Entre tanto, su hija Sancha era criada por sus tías las infantas doña Sancha y doña Elvira, quienes en esos momentos disfrutaban el honor del Infantado, cuya cabeza seguía siendo San Isidoro de León. Aquí se recluye su madre doña Urraca después de su ruptura definitiva con Alfonso de Aragón en 1114. Sin embargo, este reclutamiento no le proporcionó la paz que probablemente buscaba cuando llegó, ya que pronto comenzaron las discrepancias con su hijo Alfonso por la posesión del reino, hasta la fecha de 1117, cuando firman un acuerdo por el cual Alfonso se queda con Toledo y Galicia, y la Reina Urraca queda en posesión de León. Esta

\footnotetext{
${ }^{108}$ Para Therese Martin, este es el punto que marca el cambio de la planta diseñada por la infanta Urraca de la reina. $I d$.
} 
especie de pacto se mantuvo hasta el año 1126 en que murió la Reina Urraca y Alfonso VII es coronado solemnemente como rey de León y, al igual que ocurrió con Alfonso VI y su hermana Urraca, otorga a doña Sancha el título de reina, convirtiéndose ésta en una de sus más fieles y eficientes colaboradores y consejeros, apareciendo Sancha desde estos momentos casi siempre junto a su hermano en los documentos públicos. Será también después de la muerte de la reina Urraca cuando Sancha tome posesión del título del Infantado, primero de León y posteriormente de Galicia y Asturias ${ }^{109}$. Tanto la reina Urraca como sus hijos, Alfonso VII y doña Sancha, serán también protagonistas en un momento dado de nuestra iglesia.

De este modo, la siguiente inscripción que nos encontramos en nuestra basílica relacionada con la construcción de la misma, es un epígrafe situado en el exterior del ábside central donde aparece inscrito: ERA MCLXII, correspondiente por tanto al año 1124, para el que no se ha encontrado una explicación suficientemente razonable. No hemos encontrado ninguna razón que nos llevara a dudar que el ambicioso proyecto de la infanta Urraca no estuviera terminado a su muerte en $1101 \mathrm{y}$, parece muy probable que los trabajos sufrieran una interrupción hacia 1112, debido a las constantes trifulcas entre la Reina Urraca y su segundo marido, Alfonso el Batallador ${ }^{110}$. Estas razones han llevado a Marta Poza Yagüe a interpretar la fecha de 1124 grabada en el ábside norte, como la conmemoración de la reanudación de estos trabajos, una vez pacificada la anterior situación ${ }^{111}$. Sin embargo, la profesora Therese Martin relaciona esta fecha con una marca de cantería que también encuentra, y de una manera dice "exclusiva", en la parte occidental de la iglesia, es decir, lo que es la última fase constructiva, aclarando de este modo que el significado de la inscripción debe entenderse como una conmemoración del momento en el que la iglesia de San Isidoro estuvo terminada $^{112}$.

Un hecho importante relacionado con la iglesia de León y que repercutirá directamente en nuestra iglesia de San Isidoro, fue la secularización de los canónigos de la catedral de León en el año 1144. Este hecho provocó que un pequeño grupo de ellos, encabezado por Pedro Arias, contrarios a abandonar su

${ }^{109}$ Un exhaustivo estudio sobre Alfonso VII y su hermana Sancha lo tenemos en GARCía CALLES, L., Doña Sancha hermana del Emperador, León-Barcelona, 1972.

110 A estos problemas alude don Manuel Gómez Moreno. Ver Gómez Moreno, M., El Arte Románico..., Op. cit. (n. 43), p. 106.

111 Poza YAGÜE, M., «Entre la tradición...», Art. cit. (n. 21), p. 16.

${ }^{112}$ MARTIN, Th., «Un nuevo contexto...», Art. cit., (n. 108), p. 192. 
vida regular, decidieran trasladarse a un monasterio fundado para tal efecto, y que recibió el nombre de Carvajal. Pocos años después, concretamente en 1148 y sin saberse exactamente por qué razón, doña Sancha decidió trasladar estos canónigos de Carvajal al monasterio de San Pelayo de León, donde todavía habitaban las monjas, por lo que resolvió trasladar a éstas al propio monasterio de Carvajal, quedando en posesión de los canónigos tanto el monasterio como la iglesia de San Isidoro. Muy probablemente, este traslado a San Isidoro provocó reformas en dicha iglesia, las cuales estarían finalizadas un año después en 1149, fecha conservada en un epígrafe que hace referencia a una consagración solemne que tuvo lugar el 6 de marzo de $1149^{113}$. A esta misma época pertenece una última inscripción relacionada con la construcción del edifico y que corresponde al epitafio del arquitecto Pedro Deustambem, fechado en el segundo cuarto del siglo XII, en el que aparece la palabra "superaedificavit", y traducido viene a decir:

“Aqui yace Pedro Deustambem, que terminó esta iglesia. Es también el que construyó el puente de Deustambem. Este fue un hombre de gran penitencia y que brilló por numerosos milagros; por su reputación extraordinaria. Fue enterradoe $n$ este lugar por orden del emperador Alfonso y la reina Sancha ${ }^{, 114}$.

De este modo, se atribuye a este arquitecto la conclusión del edificio con la cubrición de las bóvedas, siendo necesario el reforzamiento de los soportes de las naves, con la incorporación de pequeñas columnillas tanto en los pilares como en los muros laterales y responsiones, que incluso en algunos puntos llegan a tapar el espacio de las ventanas. Esta adición de columnas no hace otra cosa que demostrar que el edificio no estaba preparado para soportar una cubierta abovedada, entendiendo con esto que su cubrición original sería de madera y que los muros ya estaban levantados hasta esta altura de las ventanas cuando se le encargó a este arquitecto el abovedamiento del edificio. Otra peculiaridad de esta iglesia, atribuible seguramente a este arquitecto, es el hecho de que la bóveda de cañón que recorre la nave central se prolonga por el tramo del crucero y los arcos que forman

113 Para otros autores como Therese Martin, esta fecha hace alusión a una reconsagración de la iglesia por parte de Alfonso VII y su hermana Sancha, quizás con motivo de la celebración de la batalla de Baeza en 1147, o por la llegada de los canónigos a San Isidoro e incluso por la celebración de un concilio en León en el mismo año de 1149. Ver MARTIN, Th., «Un nuevo contexto...», Art. cit. (n. 107), p.192.

${ }^{114}$ En latín dice así: "Hic quiescit servís Dei Petrus d...s tam ben qui super aedificavit ecclesiam hanc isle fundavit pontem qui dicitur ds ta ben et qui erat vir mirae abstinentiae et multis florevat miraculis omnes eum laudibus praedicabant sepultus est hic ab imperatore Adefonso et Sancia regina”. Ver PÉRez LlamaZARes, J., Historia de la Real..., Op. cit. (n. 6), p. 356. 
éste tramo son polilobulados, circunstancias que han dado mucho que hablar a los historiadores.

A modo de conclusión podemos señalar, tal y como hemos podido comprobar a lo largo de este breve recorrido por la historia constructiva de San Isidoro de León, que muchos son aun los interrogantes que se plantean en relación al conocimiento de este paradigmático edificio. Algunos de ellos han sido abordados en este trabajo, mientras que otros han sido simplemente mencionados con el fin de que en un futuro se realice un completo estudio monográfico. Dicho trabajo deberá hacer especial hincapié en el estudio de las diferentes fases constructivas del edificio así como del panteón real, sin olvidar, por supuesto, un completo análisis de la escultura y la pintura, absolutamente necesarios para la comprensión total de tan emblemático edificio.

\section{LA INSTITUCIÓN DEL INFANTADO Y SU CONEXIÓN CON LA IGLESIA DE SAN ISIDORO}

Recientes estudios otorgan un papel fundamental a las mujeres reales en el patrocinio de construcciones y obras de arte relacionadas, en este caso, con San Isidoro de León ${ }^{115}$. Según estos, las diferentes fases constructivas de la iglesia de San Isidoro se deben atribuir al patrocinio único y exclusivo de mujeres de la familia real a través de la Institución del Infantado, mediante el cual adquirían un gran poder sobre la jurisdicción y administración de diferentes monasterios del reino, de los que se obtienen los beneficios necesarios para sufragar diferentes obras de arte que dieran muestra de su poder. Se deduce de diferentes fuentes y documentos que este privilegio sólo podía ser ostentado por una Infanta soltera, otorgado a ella por su padre y que sería devuelto a la línea masculina en el caso de que se casara o muriera. Pero antes de seguir, queremos aclarar en la medida de lo posible, el significado de la palabra "Infantado".

Según Luisa García Calles, no se debe hablar del Infantado como tal, sino de los Infantados, ya que había varios, y su significado equivale al de un señorío, constituido como dote de una infanta que deseaba o se comprometía a permanecer soltera. ${ }^{116}$ En determinados casos puntuales, como fue el de Doña Sancha, todos los infantados se reunieron en una sola persona $\mathrm{y}$, al contrario de lo que se ha dicho

115 Nos referimos a las investigaciones de WALKER, R., «Sancha, Urraca and Elvira: the virtues and vices of Spanish royal women 'dedicated to God'», Reading Medieval Studies, Vol. 24, 1998, pp. 113-138; CALDWELL, S., «Urraca of Zamora...», Art. cit. (n. 43); y especialmente al admirable trabajo de García Calles, L., Doña Sancha ..., Op. cit. (n. 109).

${ }^{116}$ Ibid., p. 106. 
habitualmente, no estaban formados exclusivamente por monasterios e iglesias, ni tampoco por todos los monasterios del reino, ya que muchos de ellos no pertenecieron nunca al Infantado. Sin embargo, sí es cierto que las posesiones de cada Infantado se vinculasen a un solo monasterio que es considerado como cabeza del mismo, tal y como ocurre en el caso de San Isidoro de León. De cualquier modo, hay que distinguir entre los bienes que poseían las infantas por herencia, de los que poseían plena autoridad, pudiendo así donarlos, intercambiarlos, etc..., y los bienes que poseía por derecho del Infantado, que eran en realidad una cesión del rey de determinados territorios, pero que a su muerte debían ser devueltos a la corona, hecho que delimitaría la posible potestad sobre ellos. Sin embargo, en la práctica las cosas eran muy distintas, y las infantas utilizaban las posesiones del Infantado como si de heredades se tratase. Esta potestad de las infantas se extenderá también a lo judicial, tal y como ocurría con los señores y, al parecer, ni siquiera el monarca podía entrar en la tierra "inmune" del Infantado por ningún motivo.

El nacimiento de esta institución parece estar en León y remontarse a mediados del siglo $\mathrm{X}^{117}$, cuando Ramiro II construye un monasterio para su hija Elvira, el cual formaba parte de un complejo palatino, y al que llamaron San Salvador de Palat del Rey. La única condición que se le pedía a la Infanta es que fuera "devota", que significa literalmente "prometerse a Dios", con todo lo que ello implicaba ${ }^{118}$, de lo que se deduce que esta infanta se hizo monja aunque, aunque sin embargo, no actuó como tal. Sobre este primer Infantado de León no se han conservado documentos; sí los hay por el contrario del castellano de Covarrubias. Este Infantado se formó a finales del siglo X, concretamente en 978, cuando el conde García Fernández y su mujer, accediendo al deseo de su hija mayor Urraca, compraron el monasterio de los Santos Cosme y Damián, en esos momentos un cenobio dúplice, para que ésta sirviera a Dios, junto con todos sus alrededores. Más tarde, este territorio se conoció como el "Infantado de Covarrubias", cuya cabeza era este monasterio de San Cosme y San Damián, en el que la Infanta a su ingreso tomó el hábito.

En el caso que nos ocupa, el Monasterio de San Pelayo se constituyó prácticamente desde su nacimiento como cabeza del Infantado, sustituyendo a San

117 Decimos "parece" porque de los orígenes del Infantado de León no se conserva ninguna escritura de fundación, sin embargo no parece haber ninguna duda entre los investigadores de que se instituyó en este siglo y de que su rama primitiva fue la del valle del Torio. Ver GARCía CALLES, L., Doña Sancha..., Op. cit. (n. 109), p. 114.

${ }^{118}$ WALKER, R., «Sancha, Urraca and Elvira...», Art. cit. (n. 115), p. 114. 
Salvador de Palat del Rey, en el que fueron profesando sucesivas princesas. Las primeras noticias que tenemos sobre él, proceden de la hermana de Alfonso V, la Infanta doña Teresa, quien ingresó en el monasterio desde donde ejerció su derecho sobre el Infantado. Este privilegió pasó después a doña Sancha, hija de Alfonso V y hermana del rey Bermudo III, quien antes de su matrimonio con Fernando I ostentó la dignidad de abadesa. Es curioso el caso de esta Infanta, pues una vez casada no devolvió el Infantado, sino que lo conservó e hizo uso de él. Por tanto, no nos debe extrañar, que este interés y predilección por León y concretamente por San Isidoro, tenga relación con el Infantado y sus posesiones.

A la muerte de Fernando I, éste dejó a sus hijas Urraca y Elvira todo el Infantado, junto con los monasterios por él edificados, quedando finalmente por entero en manos de la primera, tras el matrimonio de su hermana Elvira. Urraca vivió en el palacio adjunto al monasterio de San Isidoro, sin embargo, no fue una monja, puesto que al parecer, no vestía como tal. A pesar de su devoción y de su vida piadosa, su figura ha sido enturbiada por los cronistas de los siglos XII y XIII, quienes la describen como una mujer conspiradora y malvada, que incluso llegó a ordenar el asesinato de su hermano Sancho para facilitar el camino a su hermano Alfonso VI en su pretensión de llegar a Emperador. Ciertos o no estos rumores, el caso es que la infanta Urraca permaneció toda su vida cerca de su hermano Alfonso, quien la otorgó incluso el título de reina y todo parece indicar que fue ella exclusivamente la que decidió la ampliación de la Iglesia de sus padres, y ella también la única que se encargó de sufragar todos los gastos. Sin embargo, de este patronazgo no se conserva absolutamente ningún documento, excepto la dudosa alusión de su epitafio, aunque también es cierto que las fuentes no aluden a Alfonso VI como patrocinador de las obras.

A Alfonso VI le sucedió en el trono su hija Urraca, quien se casó dos veces por lo que no pudo tener acceso al privilegio del Infantado, que en esos momentos estaba en posesión de las infantas Sancha y Elvira. No obstante, tras la separación de su segundo marido, se recluyó en el monasterio de San Isidoro, lo que demuestra que estuvo íntimamente ligada a la vida del mismo y como no, también fue partícipe de su construcción.

Finalmente, heredará el Infantado la hija de la Reina Urraca y hermana de Alfonso VII, la infanta Sancha, quien curiosamente tomará posesión del Infantado únicamente después de la muerte de su madre. Parece ser que la iglesia se concluyó durante el reinado de su hermano o, al menos, así consta en la inscripción de su consagración en 1149. También aparece aquí la infanta como Domina y a ella se atribuye la decisión de trasladar a las monjas que todavía habitaban en él al Monasterio de Carvajal, para así traer desde éste a los canónigos que en él vivían. 
Es lógico pensar que este repentino traslado provocara reformas en la Iglesia y que éstas fueran sufragadas por la propia Infanta, además de encargar al arquitecto Pedro Deustambem la cubrición con bóvedas de todo el edificio.

Muerta doña Sancha, el Infantado desaparece prácticamente como tal, puesto que ya no será patrimonio de las princesas reales que permanecieran solteras. Este hecho fue provocado principalmente por la división de los reinos de Castilla y León tras la muerte del Emperador, quedando el de Castilla sin infantas, lo que condujo a Alfonso VIII a ceder los bienes del Infantado a diferentes iglesias, como la abadía de Covarrubias o el monasterio de las Huelgas. En cuanto al Infantado de León, un documento fechado en 1165 atestigua que Fernando II donó a su hermana Sancha, reina de Navarra, todo el Infantado de su reino ${ }^{119}$.

Analizando lo anteriormente expuesto, no parece haber ninguna duda en relacionar las diferentes fases constructivas de San Isidoro de León con el patrocinio de las Dominas del Infantado del reino. Sin embargo, queda un importante problema por resolver como es el hecho de averiguar qué papel jugaron estas infantas en el cambio de liturgia, puesto que como ya hemos visto, a ellas pertenecía la jurisdicción plena de los monasterios, tanto masculinos como femeninos, que formaban parte del Infantado. Habría que empezar, no obstante, por averiguar en qué monasterios se produjo por primera vez este cambio y si éstos pertenecían o no en esos momentos al Infantado. Somos conscientes de lo arduo de esta tarea, máxime dada la fecha en la que se produjo este cambio, en pleno siglo $\mathrm{XI}$, una de los períodos peor estudiado de nuestra historia medieval.

\section{RELACIÓN DE IMÁGENES INCLUIDAS EN EL ARTÍCULO}

- Fig. 1: Panteón y restos de la iglesia de San Isidoro de León según GóMEZ Moreno, M., El arte románico español. Esquema de un libro, Madrid, 1934

- Fig. 2: Panteón y galerías circundantes según WILLIAMS, J., «San Isidoro in León: Evidence for a New History», The Art Bulletin, ${ }^{\circ} 55$ (2), 1973, pp. 171-184.

- Fig. 3: Iglesia de San Isidoro de León según GóMEZ MorENO, M., El arte románico español. Esquema de un libro, Madrid, 1934.

- Fig. 4: Sucesivas campañas constructivas de la iglesia de San Isidoro de León según CALDWELL, S., «Urraca of Zamora and San Isidoro in León: Fulfillment of a Legacy», Woman's Art Journal, nº 7 (1), 1986, pp. 19-25.

${ }^{119}$ García Calles, L., Doña Sancha ..., Op. cit. (n. 109), p. 122. 


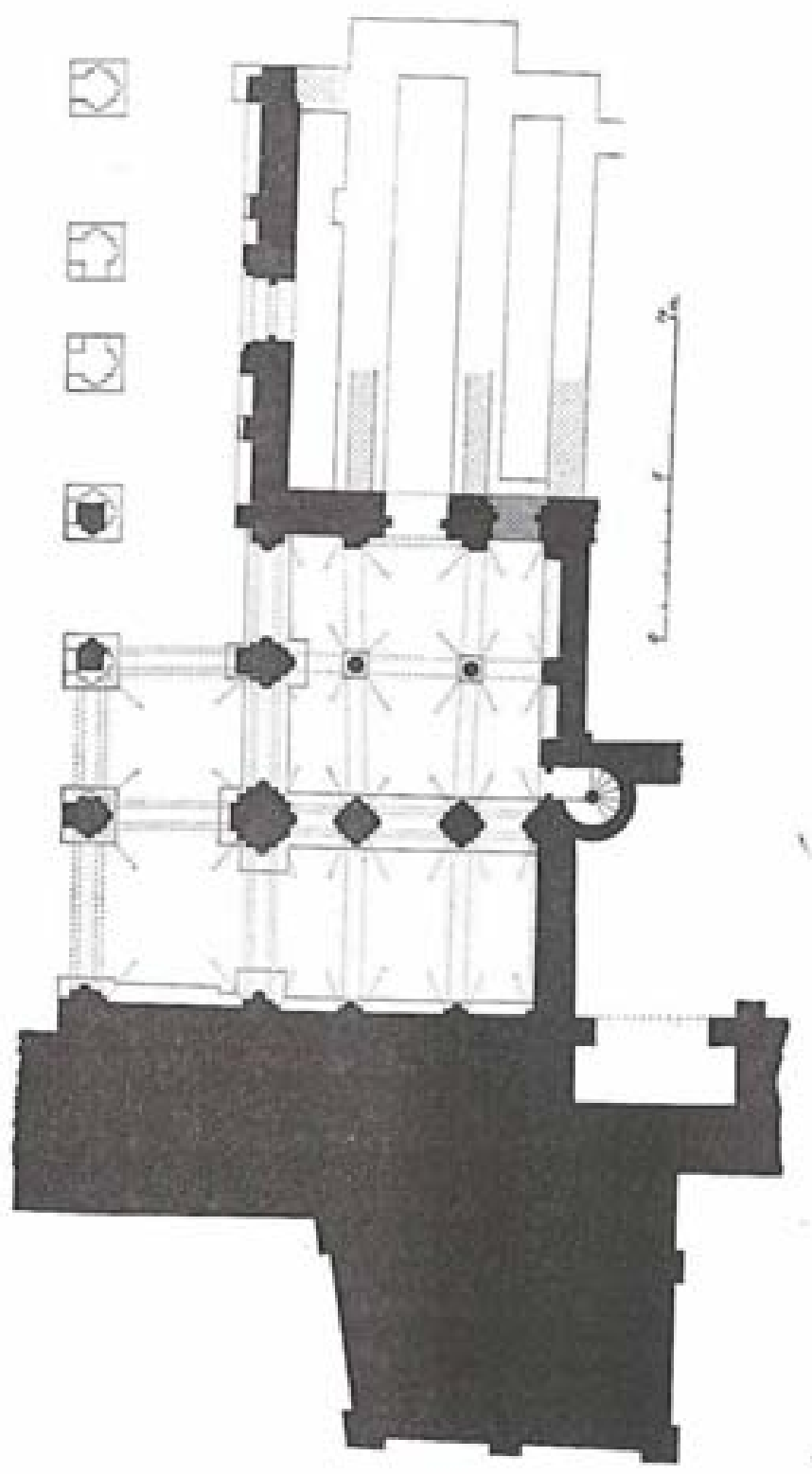

Fig. 1: Panteón y restos de la iglesia de San Isidoro de León según GÓMEZ MORENO, M., El arte románico español. Esquema de un libro, Madrid, 1934. 


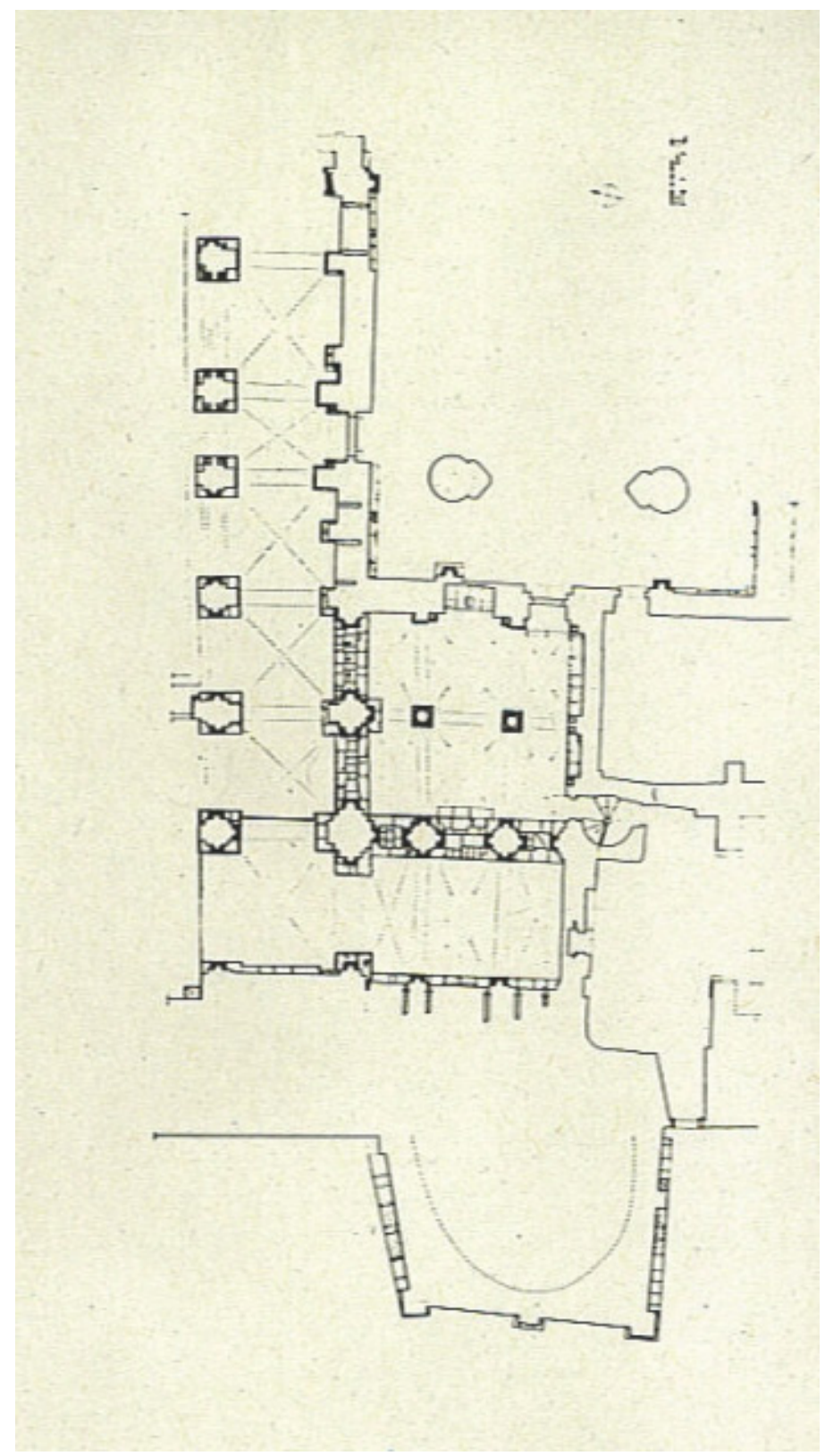

Fig. 2: Panteón y galerías circundantes según WILLIAMS, J., «San Isidoro in León: Evidence for a New History», The Art Bulletin, $n^{\circ} 55$ (2), 1973, pp. 171-184. 


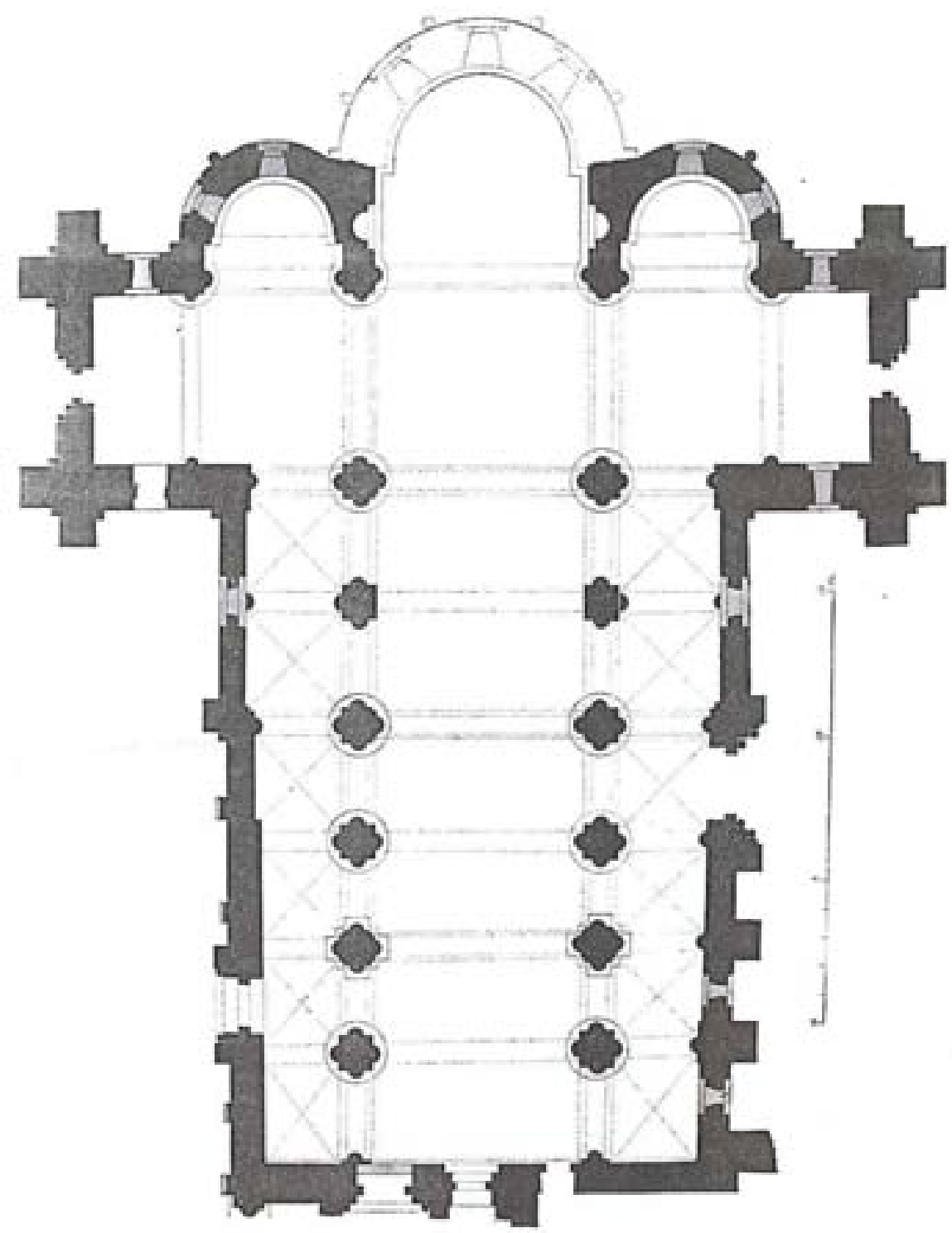

Fig. 3: Iglesia de San Isidoro de León según Gómez Moreno, M., El arte románico español. Esquema de un libro, Madrid, 1934. 


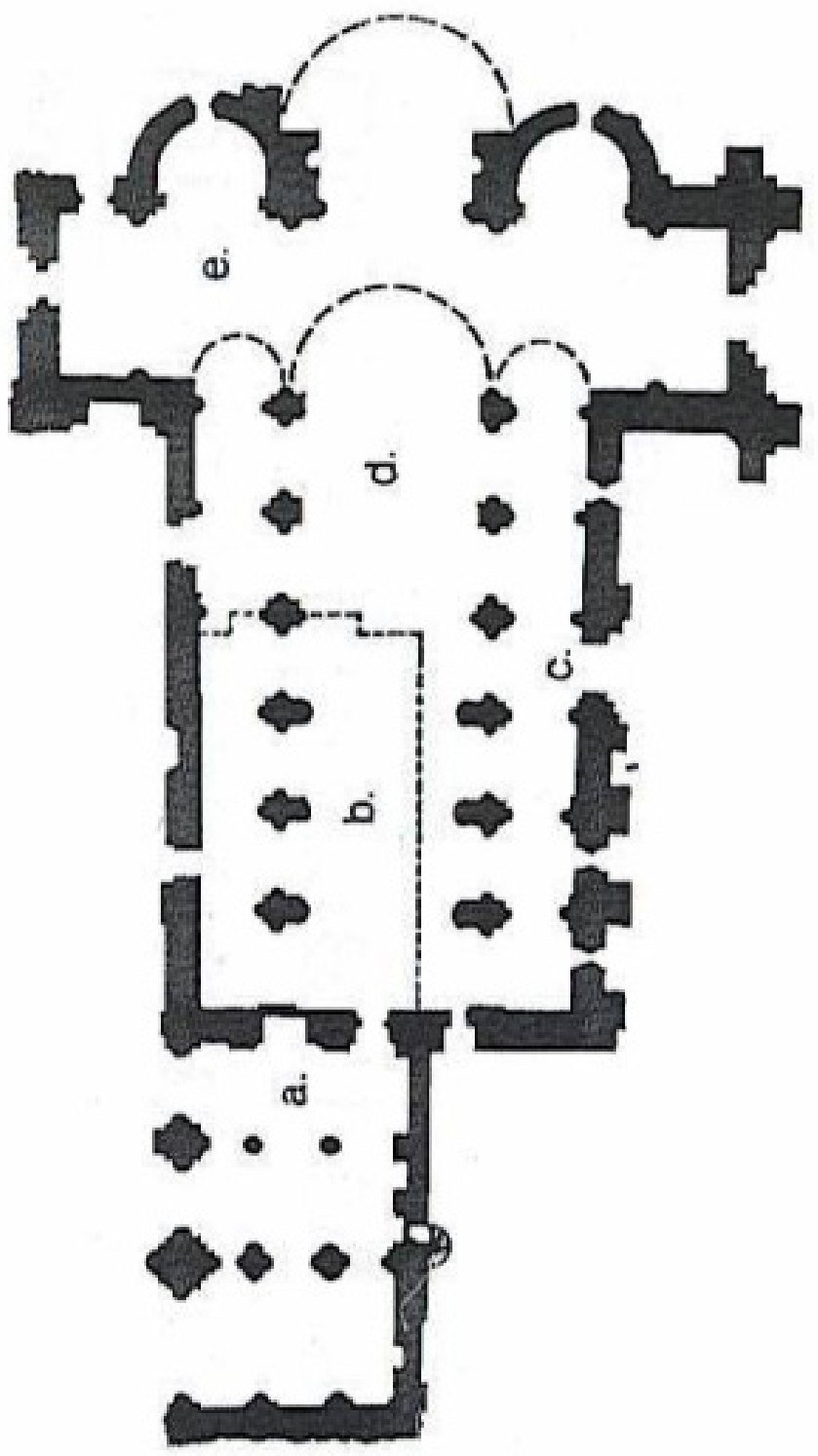

Fig. 4: Iglesia de San Isidoro de León según GÓMEZ MORENO, M., El arte románico español. Esquema de un libro, Madrid, 1934. 


\section{BIBLIOGRAFÍA}

Enciclopedia del Románico en Castilla y León, (Dir. GARCíA GuINEA, M. A.), Aguilar de Campoo, 2002.

Historia Silense, Ed. de PÉRez De Urbel, J., y GonZÁlez Ruiz-Zorrilla, A., Madrid, 1959.

BANGO TORVISO, I. G.: «Atrio y pórtico en el Románico español: concepto y finalidad cívico-litúrgica», Boletín de Seminario de Estudios de Arte y Arqueología, Tomos XL-XLI, Valladolid, 1975, pp. 175-188.

BAngo ToRviso, I. G.: Alta Edad Media. De la tradición hispanogoda al Románico, Madrid, 1989.

BANGO TORVISO, I. G.: «La iglesia de Silos: Del prerrománico al románico pleno», El románico en Silos. IX Centenario de la Consagración de la iglesia y claustro (1088-1988), Abadía de Silos, 1990, pp. 317-376.

BANGO TORVISO, I. G.: «El camino jacobeo y los espacios sagrados durante la Alta Edad Media en Espana», Viajeros, peregrinos, mercaderes en el Occidente Medieval. XVIII Semana de Estudios Medievales, Estella 1991, Navarra, 1992, pp.121-155.

BANGO TORVISO, I. G.: «El espacio para enterramientos privilegiados en la arquitectura medieval española», Anuario del Departamento de Historia y Teoría del Arte (U.A.M), Vol. IV, 1992, pp. 93-132.

BANGO TORVISO, I. G.: El Románico en España, Madrid, 1992.

BANGo TORviso, I. G.: «Arquitectura y escultura», Historia del Arte de Castilla y León. Arte Románico, Tomo II, Valladolid, 1994, pp. 9-212.

BANGO TORVISO, I. G.: El arte románico en Castilla y León, Madrid, 1997.

BANGO TORVISO, I. G.: «La piedad de los reyes Fernando I y Sancha. Un tesoro sagrado que testimonia el proceso de la renovación de la cultura hispana del siglo XI», Maravillas de la España Medieval: Tesoro sagrado y monarquía, León, 2001, pp. 223-227.

BANGO TORVISO, I. G.: Arte prerrománico hispano. El arte en la España cristiana de los siglos VI al XI, en Summa Artis. Historia General del Arte, Vol. VIII-II, Madrid, 2001.

BANGO TORVISO, I. G.: "Arquitectura y escultura monumental», Historia de España de Menéndez Pidal, Tomo XI, Madrid, 2001, pp. 344-414.

BISHKO, Ch.: «Liturgical intercesión at Cluny for the king-emperors of León», Studia Monástica, vol. 3, 1961, ppp. 53-76.

BISHKO, Ch.: «Fernando I y los Orígenes de la alianza castellano-leonesa con Cluny», Cuadernos de Historia de España, vol. XLVII-XLVIII, 1968, pp. 31135. 
BISHKO, Ch.: «The Liturgical Context of Fernando I's Last Days According to the So-Called 'Historia Silense'». Miscelánea en Memoria de Dom Mario Férotin, 1914-1964. Hispania Sacra, Vols. XVII-XVIII, 1964-1965, pp. 47-59.

CALDWELL, S.: «"Urraca of Zamora and San Isidoro in León: Fulfillment of a Legacy», Woman's Art Journal, no 7 (1), 1986, pp. 19-25.

CALDWELL, S.: «Queen Sancha's "Persuasion". A Regenerated León Symbolized in San Isidoro's Pantheon and its Treasures», Global Publications Center for medieval \& Renaissance Studies, Binghamton University, State University of New York, 2000. This essay was presented most recently at the Conference "The Poetics of Space" March 10-11, 2000 sponsored by the Department of Romance Languages and Literatures in the session "The Space of Empire".

CAstiñeiras GonzÁlez, M. A., «El programa enciclopédico de la Puerta del Cielo en el Panteón Real de San Isidoro de Leon», Compostellanum, vol. XLV, $n^{\circ} .3-4,2000$.

Conant, K. J., Arquitectura Carolingia y Románica: 800-1200, Madrid, 2001.

Cosmen Alonso, Ma . C., Dos iglesias románicas del Bierzo: San Miguel y San Esteban de Corullón, León, 1985.

DíAZ-JimÉNEZ, J. E., «San Isidoro de Leon», Boletín de la Sociedad Española de Excursiones, Madrid, 1917, pp. 81-98.

Durliat, M., L'Art Roman en Espagne, París, 1962.

FERNÁNDEZ GonZÁlez, E., San Isidoro de León, Madrid, 1991.

FERnÁndez SomozA, G., "Cruz de Fernando I y Sancha», Maravillas de la España Medieval: Tesoro Sagrado y Monarquía, León, 2001, pp. 230-231, n ${ }^{\circ}$ cat. 88 .

Franco MATA, Ma . A., «El tesoro de San Isidoro y la monarquía leonesa», Boletín del Museo Arqueológico Nacional, n. IX, 1991, pp. 35-67.

GAILlARD, G.:Les débuts de la sculpture romane spagnole. Leon, Jaca, compostelle, París, 1938.

GAILlARD, G.:La sculpture romane espagnole 1. De Saint Isidore de Leon à Saint Jacques de Compostelle, París, 1946.

GALTIER MARTI, F., «Le corps occidental des égleses dans l'art roman espagnol du XI s.: problèmes de réception d'un modèle septentrional», Cahiers de Civilisation Médievale, vol. XXXIV, 1991, pp. 297-307.

García Calles, L., Doña Sancha hermana del Emperador, León-Barcelona, 1972.

GARCÍA Romo, F., «Los pórticos de San Isidoro de León y de Saint-Benoit-surLoire y la Iglesia de Sainte-Foy de Conques», Archivo Español de Arte, n .28 , 1955, pp. 207-236.

GÓMEZ MORENO, M.:Iglesias mozárabes, Madrid, 1919 
Gómez Moreno, M.:Catálogo Monumental de España. Provincia de León, Madrid, 1925.

GÓMEZ MORENO, M.:El arte románico español. Esquema de un libro, Madrid, 1934.

LuCAS DE TúY, Milagros de San Isidoro, Traducción de Juan de RoBLES, Trascripción, prólogo y notas de Julio PÉREZ LLAMAZARES, León, 1992.

MARTIN, Th.:Queen as king: Patronage at the Romanesque Church of San Isidoro de León, University of Pittsburgh, 2000.

MARTIN, Th.: «Un nuevo contexto para el tímpano de la portada del Cordero en San Isidoro de Leon», El tímpano Románico, imágenes, estructuras y audiencias, Santiago de Compostela, 2003, pp. 182-205.

MÉlidA, J. R., «La Basílica legionense de San Isidoro», Boletín de la Real Academia de la Historia, Tomo LVI, 1910, pp. 148-153.

MENÉNDEZ PIDAL, R., La España del Cid, Vol. I, Madrid, 1969.

Morales, A., Viaje Santo. Viaje a los Reinos de Leon, y Galicia, y Principado de Asturias, Ed. Facsímil, Oviedo, 1977.

MORALEJO, S.:«Artistas, patronos y público en el arte del Camino de Santiago», Compostellanum, XXX, nº 3-4, 1985, pp. 395-423.

MORALEJO, S.:«Le origini del programma iconografico dei portali nel romanico spanoglo», Actas. Wiligelmo e Lanfranco nell'Europa romanica, Módena, 1989, pp. 35-51.

PASTRANA GARcíA, J., San Isidoro de León, León, 1964.

PÉREZ Llamazares, J., Historia de la Real Colegiata de San Isidoro de León (Edición facsimil), León, 1927.

PozA YagüE, M., «Entre la tradición y la reforma. A vueltas de nuevo con las portadas de San Isidoro de Leon», Anuario del Departamento de Historia y Teoría del Arte (U.A.M), Vol. XV, 2003, pp. 9-28.

Risco, M., Iglesia de León, y Monasterios antiguos y modernos de la misma ciudad, Madrid, 1978.

RoBB, D., «The Capitals of the Panteón de los Reyes, San Isidoro de Leon», The Art Bulletin, no 27 (3), 1945, pp. 165-174.

SchlunK, H., y Manzanares, J., «La Iglesia de San Pedro de Teverga y los comienzos del arte románico en el Reino de Asturias y Leon», Archivo Español de Arte, XXIV, 1951, pp. 277-305.

SENRA, J. L., «Aproximación a los espacios litúrgico-funerarios en Castilla y León: pórticos y galileas», Gesta, vol. XXXVI (2), 1997.

Serrano, L., Cartulario de San Pedro de Arlanza, Madrid, 1925.

SuÁrEZ GONZÁlEZ, A., "Aproximación a la comunidad de San Isidoro de León entre 1156 y 1248 (Estudio Cuantitativo y cualitativo)», Estudios Humanísticos. Geografía, Historia y Arte, nº 14, 1992, pp.145-175. 
VALDEZ Del Álamo, E., «Ortodoxia y Heterodoxia en el estudio de la Escultura Románica Española: Estado de la cuestión», Anuario del Departamento de Historia y Teoría del Arte (U.A.M), Vols. IX-X, 1997-1998, pp. 9-33.

VAldÉs FernándeZ, M., »El Panteón Real de la Colegiata de San Isidoro de Leon», Maravillas de la España Medieval: Tesoro sagrado y monarquía, León, 2001.

VIÑAYO, A.:«Cuestiones histórico-críticas en torno a la traslación del cuerpo de San Isidoro», Isidoriana, León, 1961, pp. 285-297.

VIÑAYO, A.:«La llegada de San Isidoro a León. Datos para la historia del traslado del Cuerpo del Doctor de las Españas desde Sevilla a León (1063)», Archivos leoneses, $\mathrm{n}^{\mathrm{O}} 33$ (XVII), 1963, pp. 65-112.

VIÑAYO, A.:«El arte románico leonés. Nuevas cuestiones», León medieval. Doce estudios, León, 1978, pp. 221-232.

VIÑAYO, A.:La Colegiata de San Isidoro, Madrid, 1979.

VIÑAYO, A.:San Isidoro de León. Panteón de Reyes. Albores románicos: arquitectura, escultura y pintura, León, 1995.

WALKER, R.:«Sancha, Urraca and Elvira: the virtues and vices of Spanish royal women `dedicated to God'», Reading Medieval Studies, Vol. 24, 1998, pp. 113138.

WALKER, R.: «The Wall Painting in the Pantheón de los Reyes at León: A cycle of Intercession», The Art Bulletin, Vol. LXXXII (2), 2000, pp. 200-225.

WiLliamS, J.:«San Isidoro in León: Evidence for a New History», The Art Bulletin, $\mathrm{n}^{\circ} 55$ (2), 1973, pp. 171-184.

WILLIAMS, J.:«Generationes Abrahae: Reconquest Iconography in León», Gesta, vol. XVI (2), 1997, PP. 3-14.

WiLliaMS, J.:«León and the beginnings of the Spanish Romanesque», The Art of the Medieval Spain: ad 500-1200, The Metropolitan Museum of Art, New York, 1993, pp. 167-173.

WILLIAMS, J.:«León: The Iconografy of the Capital», Cultures of power: Lordship, status and process in Twelfth-century Europe, 1995, pp. 231-258.

YARZA, J., Arte y arquitectura en España: 500-1250, Madrid, 2000. 
